Apples and Oranges:

An International Comparison of the Public's Experience of Justiciable Problems and the Methodological Issues Affecting Comparative Study

P Pleasence $^{1 *}$, N J Balmer ${ }^{1}$ and R L Sandefur ${ }^{2}$

${ }^{1}$ University College London

${ }^{2}$ University of Illinois, Champaign-Urbana

*Author and address for correspondence and requests for reprints

Pascoe Pleasence

University College London

Bentham House

Endsleigh Gardens

London, WC1H 0EG 


\title{
Apples and Oranges: \\ An International Comparison of the Public's Experience of Justiciable Problems and the Methodological Issues Affecting Comparative Study
}

\begin{abstract}
Since the mid-1990s, at least 28 large-scale national surveys of the public's experience of justiciable problems have been conducted in at least 15 separate jurisdictions, reflecting widespread legal aid reform activity. While the majority of these surveys take their structure from Genn's Paths to Justice survey (1999), they vary significantly in length, scope, mode of administration, types of problems included, survey reference period, data structure, data analysis and question formulation.

This paper draws upon surveys from across the world, contrasting their methodologies, comparing their headline findings, and setting out the potential for bias as a consequence of methodological variation. The paper also presents findings from five online experiments testing the impact of various question formulations on problem prevalence, use of advice and formal processes. Specifically, the experiments test whether varying the reference period, describing problems as 'legal', offering detailed as opposed to simple problem descriptions and describing problems as 'difficult to solve' had an impact on reported prevalence of justiciable problems, and whether presenting lists as opposed to a series of individual questions had an impact on reported use of advice and processes.

The experiments demonstrated that modest differences in question formulation yield significantly different results. Specifically, alteration of survey reference period did not result in a proportional change in reported problem prevalence, introducing problems as either 'legal' or 'difficult to solve' significantly reduced reported prevalence, and introducing use of advice/processes as multiple questions rather than as lists significantly increased reported use.

The risks involved in comparative analysis (and particularly in looking beyond methodology when attempting to explain jurisdictional variation) are discussed. In relation to future studies, the importance of understanding the impact of methodological change, learning the lessons of the past, making technical details transparent and making data available are highlighted.
\end{abstract}




\section{Apples and Oranges: \\ An International Comparison of the Public's Experience of Justiciable Problems and the Methodological Issues Affecting Comparative Study}

\section{Introduction}

Since the mid-1990s, large scale national surveys of the public's experience of justiciable problems - problems which raise civil legal issues, whether or not this is recognised by those facing them and whether or not any action taken to deal with them involves the legal system (Genn 1999, p.12) - have been conducted in at least 15 separate jurisdictions: Australia, Bulgaria, Canada, England and Wales, Hong Kong, Japan, Moldova, the Netherlands, New Zealand, Northern Ireland, Scotland, Slovakia, Taiwan, Ukraine and the United States (Table 1). ${ }^{1}$ Extensive sub-national surveys have also been conducted in China (Michelson 2008) and Russia, ${ }^{2}$ along with many other sub-national surveys across the jurisdictions just listed. ${ }^{3}$

These surveys, commonly known as 'legal needs' surveys, have their ultimate origins in Clark and Corstvet's (1938) landmark study of "how the needs of the community for legal service were being met" in Connecticut during the 1930s recession at the United States' Bar. However, although Clark and Corstvet anticipated that similar surveys would become commonplace, ${ }^{4}$ few further surveys were conducted in the decades that followed. Only in the 1990s did such research "gain considerable momentum" (Coumarelos et al 2012, p.1) following the conduct of high profile national surveys in, first, the United States (Reese and Eldred 1994), then England and Wales (Genn 1999), New Zealand (Maxwell et al 1999) and Scotland (Genn and Paterson 2001). ${ }^{5}$ Momentum has been fuelled by widespread legal aid reform activity across the globe, with the introduction of civil legal aid in countries such as Bulgaria and Moldova, ${ }^{6}$ the expansion of civil legal aid in countries such as Taiwan, ${ }^{7}$ and substantial (and on-going) reform of established civil legal aid schemes, such as that in England and Wales (Lord Chancellor's Department 1998, Legal Services Commission 2006, Ministry of Justice 2010).

Reflecting concerns about the preclusion of problems that "may not be seen" by respondents to raise legal issues (Maxwell et al 1999, p.17), most recent surveys have adopted the practice of presenting justiciable problems as simple sets of circumstances, "without labeling them as legal needs or susceptible to legal intervention" (Reese and Eldred 1994, p.9). This practice also links to developments in thinking around the contested notion of 'legal need'. In particular, it links to general recognition that legal mechanisms do not always provide the most appropriate route to solving problems that raise legal issues (e.g. Lewis 1973, Blacksell et al 1991). Recent surveys have therefore

\footnotetext{
1 Reese and Eldred (1994), Genn (1999), Maxwell et al (1999), Genn and Paterson (2001), Pleas ence et al (2004a), Currie (2005), GfK Slovakia (2004), Van Velthoven and ter Voert (2004), Currie (2006), Dignan (2006), Ignite Research (2006), Pleasence (2006), Murayama (2007), Sato et al (2007), Asia Consulting Group Limited and Policy 21 Limited (2008), Currie (2009), Tamaki, T. (2009), Pleasence et al (2010), Van Velthoven and Haarhuis (2010), Pleasence et al (2011), Chen et al (2012), Coumeralos et al (2012). Details of the Bulgarian and Moldovan surveys kindly provided by Martin Gramatikov.

2 Details of the Russian survey kindly provided by Martin Gramatikov.

${ }^{3}$ For example, over the past two decades, surveys have been conducted in at least 16 of the 50 US states, as well as in other jurisdictions such as Australia (Coumarelos et al 2006) and Canada (Baxter et al 2012).

${ }^{4}$ Clark and Corstvet (1938, p. 1273) hoped that "a substantial number of local surveys" would be carried out which, together, would "afford a picture fairly representative of conditions across [the United States]."

5 Themselves influenced by an earlier wave of surveys including the earlier American Bar Association and American Bar Foundation survey (Curran \& Spalding 1974) and the Civil Litigation Research Project (Trubek et al 1983), which also led to efforts of replication (e.g. Bogart and Vidmar 1990).

${ }^{6}$ Legal Aid Act 2005 (Bulgaria); Legal Aid Act 2007 (Moldova)

${ }^{7}$ Legal Aid Act 2004
} 
tried to adopt a more neutral stance towards citizen behaviour and what constitutes (the equally contested notion of) access to justice.

\section{A. A World of Difference}

The great majority of the 28 national surveys listed in Table 1 have adopted the approach and questionnaire structure of Genn's $(1999,2001)$ ground-breaking Paths to Justice surveys, conducted in England and Wales in 1997 and Scotland in 1998. Only the earlier United States Comprehensive Legal Needs Study (Reese and Eldred 1994) and contemporaneous New Zealand Legal Advice and Assistance Survey (Maxwell et al 1999) fall outside of the Paths to Justice sphere of influence.

Table 1: National Legal Needs Surveys (Last 20 Years)

\begin{tabular}{|c|c|c|c|c|c|}
\hline Country & Study & Date & Size & $\begin{array}{c}\% 1+ \\
\text { problems }\end{array}$ & $\begin{array}{c}\% \text { lawyer } \\
\text { use }\end{array}$ \\
\hline Australia & Law Australia Wide Survey & 2008 & 20716 & 46 & 11 \\
\hline Bulgaria & Access to Justice and Legal Needs Bulgaria & 2007 & 2730 & 46 & 15 \\
\hline \multirow[t]{3}{*}{ Canada } & \multirow[t]{3}{*}{ National Survey of Civil Justice Problems } & 2004 & 4501 & 48 & NR \\
\hline & & 2006 & 6665 & 45 & 12 \\
\hline & & 2008 & 7002 & 55 & NR \\
\hline \multirow{7}{*}{$\begin{array}{l}\text { England and } \\
\text { Wales }\end{array}$} & Paths to Justice & 1997 & 4125 & 39 & 27 \\
\hline & \multirow[t]{3}{*}{ Civil \& Social Justice Survey (CSJS) } & 2001 & 5611 & 36 & 14 \\
\hline & & 2004 & 5015 & 33 & 16 \\
\hline & & $2006-9$ & 10537 & 36 & 12 \\
\hline & \multirow[t]{2}{*}{ Civil \& Social Justice Panel Survey (CSJPS) } & 2010 & 3806 & 33 & 7 \\
\hline & & 2012 & 3911 & 33 & 6 \\
\hline & Legal Problem and Resolution Survey & $2014-15$ & 10000 & $\overline{\mathrm{NR}}$ & NR \\
\hline Hong Kong & Demand \& Supply of Legal \& Related Services & 2006 & 10385 & $19 / 32 / 40^{*}$ & $<6$ \\
\hline \multirow[t]{3}{*}{ Japan } & National Survey of Every day Life \& the Law & 2005 & 12408 & 19 & 12 \\
\hline & Access to Legal Advice: National Survey & 2006 & 5330 & 37 & 4 \\
\hline & Every day Life and Law & 2007 & 5500 & 55 & NR \\
\hline Moldova & Met and Unmet Legal Needs in Moldova & 2011 & 2489 & 22 & 4 \\
\hline \multirow[t]{3}{*}{ Netherlands } & \multirow[t]{3}{*}{ Paths to Justice in the Netherlands } & 2003 & 3516 & 67 & NR \\
\hline & & 2009 & 5166 & 61 & 11 \\
\hline & & 2013 & 5773 & NR & NR \\
\hline \multirow[t]{2}{*}{ New Zealand } & Legal Advice \& Assistance Survey & 1997 & 5431 & 51 & 18 \\
\hline & Unmet Legal Needs \& Access to Services & 2006 & 7200 & 26 & 15 \\
\hline N. Ireland & Northern Ireland Legal Needs Survey & 2005 & 3361 & 35 & 16 \\
\hline Scotland $^{8}$ & Paths to Justice Scotland & 1998 & 2684 & 26 & 29 \\
\hline Slovakia & Legal Needs in Slovakia & 2004 & 1085 & 45 & 22 \\
\hline Taiwan & Legal Dispute Settlement Behaviour & 2011 & 5601 & 57 & 5 \\
\hline Ukraine & Legal Capacity of the Ukrainian Population & 2010 & 2463 & 54 & 5 \\
\hline United S tates & Comprehensive Legal Needs Study & 1993 & 3087 & 50 & 24 \\
\hline
\end{tabular}

Notes: $\mathrm{NR}=$ Not reported. $* 1$ year/5years/lifetime

The proliferation of national legal needs studies sharing a single methodological tradition has raised the prospect of wide ranging comparative analysis. As Murayama and Cominelli (2011, p.1) have suggested, "We now have fantastic opportunities for comparative studies of civil disputes and dispute handling behaviour among countries with different socio-legal backgrounds." Accordingly, much discussion has focused on differences in justiciable problem incidence (i.e. the percentage of people experiencing one or more problems) and the frequency of distinct responses to such problems reported in different jurisdictions. For example, Van Velthoven and ter Voert $(2005$, p.21) have drawn attention to the "remarkable differences between the results of the Dutch research and those of the UK studies," in terms of Dutch respondents experiencing problems "more often" and seeking advice "less often". Similarly, Sato et al (2007) have pointed to the low

8 The experience of civil legal problems has also been asked about through the 2008/9, 2009/10, 2010/11, 2012-13 and 2014-15 Scottish Crime and Justice Surveys. 
level of advice seeking in Japan, a finding that ter Voert and Niemeijer (2007) argue reflects low levels of individualism in Japan, as reflected in Hofstede's (2001) cultural indices.

As can be seen from Table 1, there are considerable ranges of estimates of justiciable problem incidence and, for example, lawyer use among the 26 listed surveys. Reported problem incidence ranges from just $19 \%$, in the case of the 2005 Japanese survey, to $67 \%$ in the 2003 Dutch survey. The reported use of lawyers to help resolve problems ranges from 4\% in the cases of the 2006 Japanese and 2011 Moldovan surveys to $29 \%$ in the 1998 Scottish survey.

However, as Van Velthoven and ter Voert (2005, p.21) and Sato et al (2007) also cautioned, "dissimilarities may ... be caused by methodological differences" as well as cultural or situational differences. For example, Van Velthoven and ter Voert pointed out that their Dutch respondents constituted "a sample of people with access to the Internet," rather than a random sample of the population. This might have contributed to the high rate of Dutch problem incidence. As Van Velthoven and ter Voert argued, people with access to the Internet "could be more socially active, and accordingly ... in line with participation theory ... have a higher risk of disputes" (p.22). Similarly, Sato et al noted pointed out that their survey did not employ a 'triviality' filter of the type made popular by the Paths to Justice surveys to prevent surveys being overwhelmed by the quantity of problems reported. Their sample therefore included a greater number of less troublesome problems, which would not have been so likely to prompt advice seeking.

So, to what extent do differences in survey methods restrict our ability to compare and contrast the findings of the growing number of such surveys being undertaken around the globe?

In this paper we make clear the methodological differences between legal needs surveys undertaken since the mid-1990s, explain their potential effect on survey findings and illustrate the consequences of key design decisions made by survey authors. We also present the findings of a series of experiments designed specifically to test the impact of key differences in recent legal need survey design.

\section{B. $\quad$ Technical Details of Recent National Legal Need Surveys}

As can be seen from Table 2, those recent national legal need surveys that have adopted the Paths to Justice surveys' approach and structure are nevertheless methodologically distinct. There are marked differences in sample frames, sampling methods, response rates, modes of administration, data structure, units of analysis, reference periods, filtering, the justiciable problems included, framing and question formulation. Each of these differences can be expected to impact on survey findings. Only the Paths to Justice and Paths to Justice Scotland surveys were near (though not) identical in their implementation.

\section{Sample Frames, Coverage and Response Rates}

While most of the surveys in Table 2 have investigated the experience of the general adult population (albeit with varying thresholds for adulthood, from 15 years old in, for example, the 2006 New Zealand survey to 18 years old in, for example, the original Paths to Justice surveys), some have been concerned with only a section of the population.

The 2004 Canadian survey, for instance, was concerned only with those on low incomes. As demographic characteristics have been shown to be associated with both justiciable problem experience and advice seeking behaviour (e.g. Pleasence and Balmer 2012), including in Canada (Currie 2007), the narrower 2004 Canadian survey's target population will have been reflected in its findings.

This is not necessarily problematic as regards comparison with later Canadian survey findings, as it is still possible to identify the sub-sample of respondents within the 
broader 2006 sample that match those in the 2004 sample. Analyses of the 2006 survey data to identify demographic predictors of aspects of problem experience (Currie 2007) also provide a basis for understanding how modifications in sample frame scope may have impacted on findings. International comparison is more difficult, though even here equivalent populations may be identifiable.

More problematic, for comparison, is under-coverage of target populations resulting from inadequate sample frames. This can effectively preclude like-for-like comparison, as under-coverage can lead to biased estimates (e.g. de Leeuw et al., 2008) and contributes to total survey error (e.g. Groves and Lyberg, 2010).

Some of the surveys listed in Table 2 are notably affected by under-coverage, which (in the case of general population surveys) is linked to mode of survey administration. National face-to-face surveys tend to have sample frames with good coverage (Bowling 2005). For example, the Paths to Justice surveys and the English and Welsh Civil and Social Justice Surveys have all used the small user Postcode Address File (PAF) as a sample frame. This captures approximately $98 \%$ of the general population, though even here some well-defined, but relatively small, sub-populations are excluded. ${ }^{9}$ However, national telephone and Internet surveys (of which 7 feature in Table 2) are more prone to under-coverage.

Telephone surveys of the general population are becoming increasingly associated with under-coverage as a consequence of the growing proportion of (especially young and low income) adults with no fixed-line telephone (Blumberg and Luke 2007). Undercoverage of telephone surveys is also a particular issue in the case of remote indigenous populations, such as remote Australian Aboriginal and Torres Strait Islander (ASTI) people, for whom telephone surveys are "inappropriate" (Taylor et al 2011, p.5). This was recognised by the authors of the 2008 Australian survey, who had to accept that it was "unrealistic in these remote areas to achieve Indigenous numbers in proportion to the population" (Coumeralos et al 2012, p.58).

Under-coverage is most problematic, though, for Internet surveys. This is despite Internet penetration continuing to grow, removing a fundamental structural barrier to good coverage. However, in the Netherlands - one of just two jurisdictions in which large-scale national legal need studies have been conducted online - 94\% of households had Internet access in 2011, the highest rate of access in Europe. ${ }^{10}$ This is not far short of coverage for the PAF surveys detailed above. Nevertheless, the lack of comprehensive and effective sample frames remains a problem for Internet surveys, meaning that such surveys are still reliant on opt-in panel membership (as in the case of the Dutch surveys), exacerbating selection bias (Lensvelt-Mulders et al 2009) and reducing coverage dramatically. ${ }^{11}$

Selection bias is also a key feature of surveys with significant non-response, and as can be seen from Table 2, recent national legal need surveys have met varying degrees of success in convincing potential respondents to participate. Again, response rates are linked to mode of administration, with face-to-face surveys generally delivering the lowest refusal rates (e.g. see Groves et al., 2009) and generally higher response rates than telephone surveys (Sykes \& Collins, 1988; Bowling, 2005).

\footnotetext{
9 These include elderly people living in residential care, Gypsies/travellers, prisoners, military personnel living in defence establishments, persons detained under the Mental Health Act 1983, people living in (large scale) temporary accommodation, and the small number of homeless people (Pleasence et al 2011).

${ }^{10}$ Eurostat STAT/11/188, 14 December 2011.

${ }^{11}$ By way of example, for a face-to-face survey which covers around $98 \%$ of the population a problem prevalence of $35 \%$ could have an actual population prevalence of between $36.3 \%$ and $34.3 \%$ if the $2 \%$ missing from the sample frame had $100 \%$ or $0 \%$ problems respectively (using the simple formula in Groves et al., 2009). In contrast, if we were to assume that that an Internet survey with a sample frame covering $81 \%$ of the population (the percentage in the United States in 2012, assuming full opt-in) had a problem prevalence of $35 \%$, the actual population prevalence could potentially vary between 28.4 and $47.4 \%$.
} 
Table 2: Technical Details of Recent Legal Needs Surveys

\begin{tabular}{|c|c|c|c|c|c|c|c|c|c|c|}
\hline Country & Study & Date & Sample & $\begin{array}{c}\text { Sample } \\
\text { structure }\end{array}$ & Mode & $\begin{array}{l}\text { Reference } \\
\text { period } \\
\text { (Years) }\end{array}$ & $\begin{array}{c}\text { Response } \\
\text { rate } \\
(\%)\end{array}$ & $\begin{array}{l}\text { Problem framing: } \\
\text { "Problems ..." }\end{array}$ & $\begin{array}{l}\text { Number of } \\
\text { problems } \\
\text { included }\end{array}$ & $\begin{array}{c}\text { 'Difficult to } \\
\text { solve' } \\
\text { triviality filter }\end{array}$ \\
\hline Australia & Law Australia Wide Survey & 2008 & General population & Individual & Phone & 1 & 60 & $\ldots$ that may raise legal issues & 83 & No \\
\hline Bulgaria & $\begin{array}{l}\text { Access to Justice and Legal } \\
\text { Needs Bulgaria }\end{array}$ & 2007 & General population & Individual & $\begin{array}{l}\text { Face-to- } \\
\text { face }\end{array}$ & 3.5 & 51 & ... you might have experienced & 70 & No \\
\hline \multirow[t]{3}{*}{ Canada } & \multirow[t]{3}{*}{$\begin{array}{l}\text { National Survey of Civil } \\
\text { Justice Problems }\end{array}$} & 2004 & Low income & \multirow[t]{3}{*}{$\begin{array}{l}\text { Individual } \\
\& \text { partner }\end{array}$} & \multirow[t]{3}{*}{ Phone } & \multirow[t]{3}{*}{3} & 17 & $\begin{array}{l}\text {... that people sometimes } \\
\text { experience* }\end{array}$ & 79 & \multirow[t]{3}{*}{ Yes } \\
\hline & & 2006 & \multirow[t]{2}{*}{ General population } & & & & 23 & ... that affect people's lives* & 81 & \\
\hline & & 2008 & & & & & 21 & ... that affect people's lives* & 86 & \\
\hline \multirow[t]{7}{*}{$\begin{array}{l}\text { England and } \\
\text { Wales }\end{array}$} & Paths to Justice & 1997 & General population & $\begin{array}{l}\text { Household } \\
\text { / Individual }\end{array}$ & $\begin{array}{l}\text { Face-to- } \\
\text { face }\end{array}$ & 5.5 & 64 & $\ldots$ in daily life* & 58 & Yes \\
\hline & \multirow[t]{3}{*}{$\begin{array}{l}\text { Civil and Social Justice } \\
\text { Survey }\end{array}$} & 2001 & \multirow[t]{3}{*}{ General population } & \multirow[t]{3}{*}{$\begin{array}{l}\text { Household } \\
\text { / Individual }\end{array}$} & \multirow[t]{3}{*}{$\begin{array}{l}\text { Face-to- } \\
\text { face }\end{array}$} & 3.5 & 52 & $\ldots$ in daily life* & 83 & \multirow[t]{3}{*}{ Yes } \\
\hline & & 2004 & & & & 3.5 & 57 & \multirow[t]{2}{*}{... you might have had* } & 104 & \\
\hline & & $2006-9$ & & & & 3 & 58 & & 106 & \\
\hline & $\begin{array}{l}\text { Civil and Social Justice } \\
\text { Panel Survey }\end{array}$ & 2010 & \multirow[t]{2}{*}{ General population } & \multirow[t]{2}{*}{$\begin{array}{l}\text { Household } \\
\text { / Individual }\end{array}$} & \multirow[t]{2}{*}{$\begin{array}{l}\text { Face-to- } \\
\text { face }\end{array}$} & \multirow[t]{2}{*}{1.5} & 54 & \multirow[t]{2}{*}{... you might have had* } & \multirow[t]{2}{*}{104} & \multirow[t]{2}{*}{ No } \\
\hline & & 2012 & & & & & $62 * *$ & & & \\
\hline & $\begin{array}{l}\text { Justiciable Problems } \\
\text { Resolution Survey }\end{array}$ & 2014 & General population & Individual & Phone & 1.5 & No details & $\ldots$ in every day life & 57 & No \\
\hline Hong Kong & $\begin{array}{l}\text { Demand \& Supply of Legal } \\
\text { \& Related Services }\end{array}$ & 2006 & General population & $\begin{array}{l}\text { Household } \\
\text { / Individual }\end{array}$ & $\begin{array}{l}\text { Face-to- } \\
\text { face }\end{array}$ & 1/5/ Life & 66 & $\ldots$ as an individual & 67 & Yes \\
\hline \multirow[t]{3}{*}{ Japan } & $\begin{array}{l}\text { National Survey of Everyday } \\
\text { Life \& the Law }\end{array}$ & 2005 & General population & $\begin{array}{l}\text { Individual } \\
\& \text { children }\end{array}$ & $\begin{array}{l}\text { Face-to- } \\
\text { face } \\
\end{array}$ & 5 & 50 & $\ldots$ in every day life* & 66 & No \\
\hline & $\begin{array}{l}\text { Access to Legal Advice: } \\
\text { National Survey }\end{array}$ & 2006 & General population & Individual & Face to ace & 5 & 49 & $\begin{array}{l}\text { Trouble or unsatisfactory/un- } \\
\text { acceptable event }\end{array}$ & No details & No \\
\hline & Every day Life and Law & 2007 & General population & Individual & Internet & 5 & No details & $\ldots$ as listed & No details & No \\
\hline Moldova & $\begin{array}{l}\text { Met and Unmet Legal Needs } \\
\text { in Moldova }\end{array}$ & 2011 & General population & Individual & Face-to-face & 3.5 & No details & $\begin{array}{l}\text { serious and difficult to solve ... } \\
\text { needed legal measures to solve }\end{array}$ & 66 & Yes \\
\hline Netherlands & $\begin{array}{l}\text { Paths to Justice in the } \\
\text { Netherlands }\end{array}$ & 2003 & General population & Individual & Internet & 5 & 83 & $\ldots$ in daily life & 66 & Yes \\
\hline
\end{tabular}




\begin{tabular}{|c|c|c|c|c|c|c|c|c|c|c|}
\hline & & 2009 & & & & & 74 & & 68 & \\
\hline \multirow[t]{2}{*}{ New Zealand } & $\begin{array}{l}\text { Legal Advice \& Assistance } \\
\text { Survey }\end{array}$ & 1997 & General population & $\begin{array}{l}\text { Individual } \\
\& \text { children }\end{array}$ & $\begin{array}{l}\text { Face-to- } \\
\text { face }\end{array}$ & 3 & 7 & ... may have needed help & 27 & Yes \\
\hline & $\begin{array}{l}\text { Unmet Legal Needs \& } \\
\text { Access to Services }\end{array}$ & 2006 & General population & Individual & Telephone & 1 & - & $\ldots$ in daily life & 40 & Yes \\
\hline $\begin{array}{l}\text { Northern } \\
\text { Ireland }\end{array}$ & $\begin{array}{l}\text { Northern Ireland Legal } \\
\text { Needs Survey }\end{array}$ & 2005 & General population & Individual & Face-to-face & 3 & 62 & $\ldots$ that are difficult to solve & 110 & Yes \\
\hline Scotland & Paths to Justice Scotland & 1998 & General population & $\begin{array}{l}\text { Household } \\
\text { / Individual }\end{array}$ & Face-to-face & 6 & 61 & in daily life & 61 & Yes \\
\hline Slovakia & Legal Needs in Slovakia & 2004 & General population & Individual & Face-to-face & 2 & - & $\begin{array}{l}\text {... exp erienced by } \\
\text { individuals/families }\end{array}$ & 100 & Yes \\
\hline Taiwan & $\begin{array}{l}\text { Legal Dispute Settlement } \\
\text { Behaviour }\end{array}$ & 2011 & General population & $\begin{array}{l}\text { Individual } \\
\text { \& children }\end{array}$ & Face-to-face & 5 & 48 & ... that might result in a dispute & 68 & Yes \\
\hline Ukraine & $\begin{array}{l}\text { Legal Capacity of the } \\
\text { Ukrainian Population }\end{array}$ & 2010 & General population & Individual & Face-to-face & 5 & No details & Problems from a list & 44 & No \\
\hline $\begin{array}{l}\text { United States } \\
\text { of America }\end{array}$ & $\begin{array}{l}\text { Comprehensive Legal Needs } \\
\text { Study }\end{array}$ & 1993 & $\begin{array}{l}\text { Low- and mid- } \\
\text { income }\end{array}$ & Household & $\begin{array}{l}\text { Telephone/ } \\
\text { Face-to-face }\end{array}$ & 1 & 74 & $\begin{array}{l}\text { Important issues facing } \\
\text { households today } * * *\end{array}$ & 78 & No \\
\hline
\end{tabular}

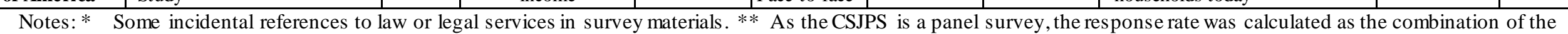
response rates for the fresh and (42.4\%) and longitudinal (69.4\%) samples. *** Some problems descriptions included the phrase 'major problem' or 'serious problem'. 
Table 2 bears this out, with the three Canadian surveys being reported to have had much lower response rates than the various face-to-face surveys; the 2008 Australian telephone survey appears to hold up well in this regard. However, the calculation of this response rate was more forgiving than for the face-to-face surveys. The Australian sample of 20,716 respondents involved in excess of half a million attempted phone contacts.

The reported response rate for the Dutch Internet surveys also appears to be high relative to the face-to-face surveys, particularly given that "the Netherlands is internationally notorious for its low response rates" (Stoop 2005, p.5). This can, though, be explained by the sample being drawn from an opt-in panel, meaning that participants had already been filtered for amenability during previous exercises. ${ }^{12}$

Nonresponse results in nonresponse error, the gap between the sample and the respondent pool (Groves et al 2009), and is a contributor to total survey error (e.g. Groves and Lyberg 2010). Error arises when the value of statistics (e.g. problem prevalence) for the survey respondents differ from those based on the entire sample. For a given statistic, nonresponse error can be calculated as the proportion failing to respond multiplied by the difference in the statistic between the respondents and the non-respondents (e.g. see Groves et al 2009). Consequently, the lower the response rate, the greater the potential for nonresponse error, though even high response rates can result in high levels of bias (i.e. where the non-respondents are particularly distinct).

The 2008 Australian survey can also be distinguished from others in its use of quota sampling, as opposed to probability sampling. While "controlled experiments between sampling methods often produce little or no difference in data," quota sampling does lack "the theoretical basis for drawing inferences from the data," making comparison more of an exercise in faith (Bradburn 1992, p.393). Though, this is no different to the position where a sample frame lacks coverage or response rates are low. All aspects of the implementation of a sample frame, along with the potential influence on results, must therefore be considered when looking to draw comparisons between findings from different surveys.

\section{2. $\quad$ Mode of Administration: Further Issues}

The surveys listed in Table 2 have employed three modes of administration: face-to-face interviews, telephone interviews and online questionnaires.

In addition to issues around coverage, as just outlined, there are other reasons why results from surveys that are differently administered can be difficult to compare.

First, questions may need to be formulated differently, depending upon mode of survey administration. As we detail in the next section, and illustrate using our experimental findings, this can significantly impact on responses. Face-to-face and Internet surveys are more suited to detailed and complex questions, and can employ show cards and visual aids to convey information and promote understanding. Indeed, Internet surveys are particularly suitable for visual enhancement (e.g. Pleasence, Balmer and Reimers 2011).

However, while Internet surveys can introduce substantial complexity, they are generally limited in their duration, needing to remain relatively short. Czaja and Blair (2005) suggest that 10-15 minutes is a long time for an Internet survey, though de Leeuw et al (2008) note the potential for longer surveys for special groups, panel members and cases where the topic is particularly salient. Telephone and, in particular, face-to-face surveys, offer greater scope for extended duration. This, in turn, means they can be more comprehensive. While interviews for the 2004 Canadian and 2006 New Zealand telephone

12 In the case of nonprobability online samples, nonresponse is typically conceptualized and measured in a different way to traditional surveys, and the nonresponse at various stages of the study/panel construction is often not reported (Baker at al 2010). 
surveys had an average duration of 15 minutes or less (Currie 2005, Ignite Research 2006), the 2008 Australian telephone survey had an average duration of 26 minutes (Coumarelos et al 2012). This is not far short of typical face-to-face surveys, which have tended to average between 30 and 40 minutes (e.g. Pleasence et al 2011).

Evidently, the duration of interviews dictates how comprehensive they can be (in terms of the range of questions asked). Thus, as in illustrated in Table 3, all of the 9 most comprehensive recent legal need surveys have been conducted face-to-face. The duration of interviews also dictates the detail of data collected within particular topic areas. So, while the face-to-face Paths to Justice surveys included 37 questions on the cost of legal services and the recent face-to-face Taiwanese survey included 20 questions on alternative dispute resolution, such detailed interrogation in relatively narrow topics was unheard of in surveys administered in different ways.

In addition to the above, face-to-face surveys are generally regarded as producing the highest quality responses, partly as a consequence of having the interviewer present (Bowling, 2005, Cooper and Schindler 2001, Curran and Blackburn 2001), which can aid comprehension, reduce item non-response (Bowling, 2005) and make complete interviews far more likely (Groves et al., 2009; de Leeuw et al., 2008).

However, the presence and greater involvement of an interviewer in face-to-face surveys is not unproblematic. As de Leeuw et al. (2008) put it, the greatest asset of face-toface surveys, the presence of an interviewer, can also be their greatest weakness. While careful briefing and monitoring of interviewers can mitigate the problem, interviewers in face-to-face surveys can more easily introduce their own misunderstandings into the data collection process. Moreover, respondents may be more concerned to present a favorable image of themselves or discuss matters of personal sensitivity in the presence of, or when talking directly to, an interviewer. ${ }^{13}$

Different modes of survey administration are also associated with different levels of 'satisficing' behaviour. Satisficing behaviour involves the taking of cognitive shortcuts to reduce the effort required to answer questions (e.g. Krosnick 1991). ${ }^{14}$ Reflecting greater satisficing behaviour in relation to online surveys, Heerwegh and Loosveldt (2008), for example, suggest that online respondents more often provide "don't know" answers, differentiate less on rating scales, and produce more item nonresponse than face-to-face respondents, resulting in data of poorer quality.

Different modes of survey administration may also promote different expectations as to subject-matter on the part of respondents. For example, the evident expense of faceto-face surveys may lead respondents to assume that they are about matters of particular significance, rather than routine or trivial matters. This could impact on the types of problems reported, and go some way to explaining the much higher problem incidence reported through Internet surveys. To counter such assumptions, clarity is required as to the nature of the subject matter of interest to the researchers.

\footnotetext{
13 The difference in responses between different modes of administration was starkly illustrated by the 1996 British Crime Survey, which incorporated a computer assisted self-interviewing (CASI) domestic violence module in addition to the usual face-to-face questioning (Mirrlees-Black \& Byron 1999). Just 32 per cent of female and 9 per cent of male respondents who reported domestic violence through the CASI module also reported it through standard interviews.

14 Tourangeau, Rips and Rasinski (2000) describe the steps required to answer questions as the interpretation of meaning and intent, the retrieval of relevant information from memory, the integration of information into a summary judgment, and the reporting of that judgment, taking into account the provided response alternatives. While many respondents may perform these steps, other res pondents may skip, or pay suboptimal attention to, one or more of them.
} 
Table 3: Topics Included in Survey Questionnaires (Where Known)

\begin{tabular}{|c|c|c|c|c|c|c|c|c|c|c|c|c|}
\hline \multirow[t]{2}{*}{ Survey jurisdiction and date } & \multicolumn{12}{|c|}{ Questionnaire topics } \\
\hline & 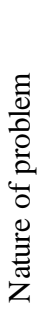 & 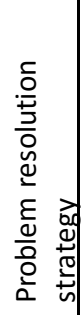 & 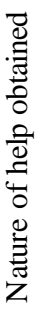 & 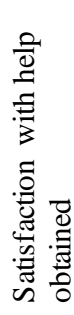 & 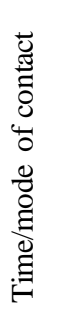 & 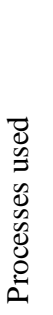 & 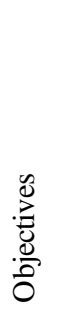 & 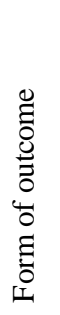 & 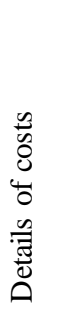 & 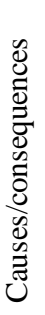 & 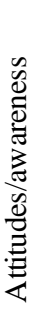 & 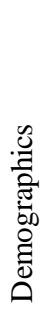 \\
\hline Australia 08 & $\bullet$ & - & - & $\bullet$ & - & • & & • & & $\bullet$ & - & $\bullet$ \\
\hline Bulgaria 07 & $\bullet$ & $\bullet$ & - & - & - & - & $\bullet$ & & $\bullet$ & & & $\bullet$ \\
\hline Canada 04 & $\bullet$ & $\bullet$ & & $\bullet$ & & $\bullet$ & & $\bullet$ & $\bullet$ & & & \\
\hline Canada 06 & $\bullet$ & $\bullet$ & & $\bullet$ & & $\bullet$ & & $\bullet$ & $\bullet$ & - & - & - \\
\hline Canada 08 & $\bullet$ & - & & - & & $\bullet$ & & $\bullet$ & $\bullet$ & $\bullet$ & $\bullet$ & $\bullet$ \\
\hline England 97 & $\bullet$ & $\bullet$ & $\bullet$ & $\bullet$ & $\bullet$ & $\bullet$ & - & $\bullet$ & $\bullet$ & & $\bullet$ & $\bullet$ \\
\hline England and Wales 01 & $\bullet$ & $\bullet$ & $\bullet$ & $\bullet$ & $\bullet$ & $\bullet$ & $\bullet$ & $\bullet$ & $\bullet$ & & $\bullet$ & $\bullet$ \\
\hline England and Wales 04 & $\bullet$ & $\bullet$ & $\bullet$ & $\bullet$ & $\bullet$ & $\bullet$ & $\bullet$ & $\bullet$ & $\bullet$ & $\bullet$ & $\bullet$ & $\bullet$ \\
\hline England and Wales 06-09 & $\bullet$ & $\bullet$ & $\bullet$ & $\bullet$ & $\bullet$ & $\bullet$ & $\bullet$ & $\bullet$ & $\bullet$ & $\bullet$ & $\bullet$ & $\bullet$ \\
\hline England and Wales 10 & $\bullet$ & $\bullet$ & • & $\bullet$ & - & - & $\bullet$ & - & $\bullet$ & $\bullet$ & - & $\bullet$ \\
\hline England and Wales 12 & $\bullet$ & $\bullet$ & $\bullet$ & $\bullet$ & $\bullet$ & $\bullet$ & $\bullet$ & $\bullet$ & $\bullet$ & $\bullet$ & $\bullet$ & $\bullet$ \\
\hline Japan 05 & $\bullet$ & $\bullet$ & $\bullet$ & $\bullet$ & $\bullet$ & $\bullet$ & & $\bullet$ & $\bullet$ & $\bullet$ & $\bullet$ & $\bullet$ \\
\hline Hong Kong 06 & $\bullet$ & - & - & - & - & $\bullet$ & $\bullet$ & - & $\bullet$ & $\bullet$ & - & $\bullet$ \\
\hline Moldova 11 & $\bullet$ & $\bullet$ & $\bullet$ & $\bullet$ & $\bullet$ & $\bullet$ & $\bullet$ & & $\bullet$ & & $\bullet$ & $\bullet$ \\
\hline Netherlands 03 & $\bullet$ & $\bullet$ & $\bullet$ & $\bullet$ & $\bullet$ & $\bullet$ & $\bullet$ & $\bullet$ & & & & $\bullet$ \\
\hline Netherlands 09 & $\bullet$ & $\bullet$ & $\bullet$ & $\bullet$ & $\bullet$ & $\bullet$ & $\bullet$ & $\bullet$ & & & & $\bullet$ \\
\hline New Zealand 97 & $\bullet$ & $\bullet$ & - & - & - & - & & $\bullet$ & & & & $\bullet$ \\
\hline New Zealand 06 & $\bullet$ & $\bullet$ & $\bullet$ & $\bullet$ & & & & $\bullet$ & $\bullet$ & $\bullet$ & $\bullet$ & $\bullet$ \\
\hline Northern Ireland 05 & $\bullet$ & $\bullet$ & - & $\bullet$ & & - & $\bullet$ & $\bullet$ & $\bullet$ & $\bullet$ & & $\bullet$ \\
\hline Scotland 98 & $\bullet$ & $\bullet$ & $\bullet$ & $\bullet$ & $\bullet$ & $\bullet$ & $\bullet$ & $\bullet$ & $\bullet$ & & $\bullet$ & $\bullet$ \\
\hline Slovakia 04 & $\bullet$ & $\bullet$ & & & & $\bullet$ & $\bullet$ & $\bullet$ & & & & $\bullet$ \\
\hline Taiwan 11 & $\bullet$ & $\bullet$ & - & $\bullet$ & $\bullet$ & $\bullet$ & $\bullet$ & $\bullet$ & $\bullet$ & $\bullet$ & - & $\bullet$ \\
\hline Ukraine 10 & $\bullet$ & & $\bullet$ & $\bullet$ & $\bullet$ & & $\bullet$ & & $\bullet$ & & & $\bullet$ \\
\hline USA 93 & $\bullet$ & $\bullet$ & $\bullet$ & $\bullet$ & & $\bullet$ & & $\bullet$ & $\bullet$ & & $\bullet$ & $\bullet$ \\
\hline
\end{tabular}

3. Framing and Question Formulation

How surveys are presented to respondents - including how they are contextualized and the research questions that are revealed) - and how particular survey questions are formulated can have a substantial impact on the nature of responses (e.g. Tourangeau et al 2000). For example, Presser et al (1992) and Galesic and Tourangeau (2007) have both demonstrated that the disclosed identity of a survey sponsor can have a significant impact on survey responses.

In the context of recent legal need surveys, some have declared sponsors that are unquestionably situated in the legal domain (e.g. 1997 New Zealand survey), others have alluded to sponsors indistinct in their domain (e.g. 2006 New Zealand survey). ${ }^{15}$ Some

15 The 1997 New Zealand Advice and Assistance Survey introduction referenced the New Zealand Legal Services Board as the survey sponsor (Maxwell et al 1999). The 2006 New Zealand survey introduced the 
have introduced survey authors evidently situated in the legal domain (e.g. 1997 Paths to Justice survey), others have referred to authors of undefined domain (e.g. 1998 Paths to Justice Scotland survey). ${ }^{16}$ Some have managed to avoid any reference to law prior to enquiring about problem incidence (e.g. 1993 US Comprehensive Legal Needs Survey, 1998 Paths to Justice Scotland survey), others have expressly referred to a law-related survey purpose (e.g. 2008 Australian Survey ${ }^{17}$ ).

Following on from Galesic and Tourangeau (2007), by putting respondents in mind of the law - either through reference to a sponsor, survey purpose of incidental reference to law - respondents might have a different propensity to participate (owing to, say, the perceived level of interest or relevance of the survey), interpret questions to be about matters they perceive as being legal (and so narrow the range of responses provided), or be reminded of experience of legal services or processes (and so boost recall of associated matters). Thus, as we later illustrate using our experimental findings, even subtle changes in framing might be expected to have some influence on results.

Turning to specific survey questions, it seems that even relatively straightforward descriptive information can vary as a result of changes in question form (e.g. Dillman 2006). Importantly, in the context of this paper, the key problem identification questions used in the 26 national legal need surveys have varied. ${ }^{18}$ While most surveys have employed questions that avoid reference to law, the 2008 Australian survey (problems or disputes "that may raise legal issues") and 2011 Moldovan survey (problems that "needed legal measures to solve") both make explicit reference to law (Table 2).

Importantly, some surveys have also adopted the wording of the original Paths to Justice survey question, which included a triviality filter requiring problems to be 'difficult to solve', while others have eschewed this on the basis that it conflates problem incidence and problem resolution behaviour (Table 2). The presence of the filter might be expected to limit the range of problems reported (as intended), impact on the pattern of problem resolution strategies associated with reported problems (difficult to solve problems might be expected to more often involve the obtaining of advice), and limit the range of respondents reporting problems (to those with less capability to deal with problems). We return to this in the context of our fifth experiment.

The English and Welsh Civil and Social Justice Survey incorporated the 'difficult to solve' filter up to 2009, after which time it was removed. While various other design changes were also made after 2009, it is interesting to note that this change saw reported problem incidence remain level despite a halving of the survey reference period, and was accompanied by a marked change in reported problem resolution strategies. So, while the 2006-9 survey indicated that $49 \%$ of problems led to formal advice being obtained, with $12 \%$ of problems leading to advice being obtained from a solicitor, the 2010 survey indicated that just $29 \%$ of problems led to formal advice being obtained, with only $7 \%$ of problems leading to advice being obtained from a solicitor. This suggests that the removal of the filter led to the reporting of a significant number of problems that were not 'difficult to solve', and which did not therefore require advice to be obtained.

sponsor (the Legal Services Agency) as "a non-profit national organisation that funds and provides services to the community."

16 The 1997 English Paths to Justice survey advance letter was written on University College London Faculty of Laws headed paper (Genn 1999).

17 The 2008 Australian survey was expressly introduced as being "on how to improve legal services" (Coumeralos et al 2012).

18 These questions are designed to identify whether respondents have experienced any justiciable problems during the survey reference period. In recent English and Welsh surveys, they have referenced 'show cards' and been phrased as follows: 'Have you had any problems or disputes of the type shown on this card since [reference date]?' 
The form of questions asking about problem resolution strategy has also varied considerably between surveys. This has even been the case between instances of the same survey. For example, there was a significant change in the way that basic problem resolution strategy was identified between the 2001 and later iterations of the English and Welsh Civil and Social Justice Survey. This was then compounded by a further change in 2010. The 2001 survey presented respondents with a list of 10 broad strategies (in terms of use of support mechanisms), ranging from doing 'nothing' to trying to 'obtain information from a lawyer or solicitor' (Pleasence et al 2004a). Apart from doing nothing, the strategies were compatible and respondents could provide multiple answers. The 2004 survey separated out different elements of problem resolving behaviour included in the list (direct negotiation, use of self-help materials, use of advice), and asked about each one separately. Those who failed to report any actions were defined as having done nothing. ${ }^{19}$ The 2010 survey reverted to the use of an initial list of strategies, but this time the components were mutually exclusive and (it was hoped) comprehensive. These changes will, as we later illustrate using our experimental findings, have impacted on findings. More generally, lists of potential answers are prone to response order effects (Groves et al., 2009), where items earlier (primacy effect) or later (recency effect) are more likely to be selected than those in the middle of lists. ${ }^{20}$

As regards international comparisons, there is also the problem of differences in terminology used to describe lawyers, other legal service providers and advisers more generally. On top of differences in the structure of legal professions, systems and markets!

4. The Range of Problems Included

As can be seen from Table 2, the number of problems included in recent national legal need surveys differs substantially. For example, while the original Paths to Justice survey included 58 specific problems, the similar 2005 Northern Ireland survey included 110.

There are also notable differences in the types of problems included in the surveys (Table 4). For example, a significant number of surveys extend beyond civil law to include the experience of crime (beyond the criminal dimensions of the included civil problems). A few also embrace business related as well as personal civil justiciable problems.

The effect of modifying the scope of a legal need survey was well illustrated by the 2008 Canadian survey, which saw the inclusion of neighbours related problems for the first time. This contributed half of the rise in the percentage of respondents reporting one or more problems from $45 \%$ in 2006 to $55 \%$ in 2008 (as ascertained by the simple removal of neighbours problems from the calculation).

Evidently, when reporting global findings (i.e. across the full range of problems surveyed), these differences in scope limit opportunities for direct comparison. And, even within relatively narrowly formulated problem categories, there are still important differences between surveys. For example, while some surveys have taken a broad approach to the 'family' problem category, extending it even as far as nursing care and inheritance (e.g. the Japanese and Taiwanese surveys), others have disaggregated problems concerning family breakdown from other types of family related problems (e.g. the English and Scottish surveys). Similarly, some surveys have taken a broad approach to the

\footnotetext{
19 This also hints at one of the problems of comparing rates of 'lumping' (e.g. Genn 1999) between surveys and jurisdictions. Namely, the different ranges of problem resolving behaviour asked about in surveys leading to differently composed residual groups of those taking 'no' action. This was addressed in the 2010 English and Welsh Civil and Social Justice Panel Survey (for detailed questioning only) by asking, at the end, about any other actions taken.

${ }^{20}$ In fact, the extent and direction of response order effects has also been shown to vary by mode (e.g. Bishop et al., 1988; Schwarz et al., 1991; Tourangeau, Rips and Rasinski, 2000).
} 
'housing' problem category, extending it to problems faced by both tenants and owneroccupiers (e.g. the 2006 New Zealand and Canadian surveys), others have dealt with these separately (e.g. the earlier New Zealand and Bulgarian surveys).

As with questions around problem resolution strategy, the composition of problem categories sometimes changes even between instances of the same survey. For example, while the 2004 and 2008 Canadian surveys both included 7 types of money/debt problem, only 2 of the 7 were exactly the same. Some were very different. For example, the later survey restricted the problem of being subjected to procedures for the recovery of outstanding debt to occasions of 'being harassed persistently'. It also introduced the wholly new problem of being mis-sold financial products. Such changes must affect reporting patterns and may well have contributed to the drop in incidence of money/debt problems, from $27 \%$ to $20 \%$, between the two surveys.

Linked to this, the level of detail in descriptions of the problems under investigation presented to respondents has also varied considerably. The amount of detail in questions may have bearing on the accuracy of reporting. If there is too much detail in the questions, 'excessive complexity' may result in questions that prevent respondents from inferring the intended meaning (Groves et al., 2009). This could increase or decrease problem prevalence depending on how the question is interpreted. Conversely, a lack of detail may affect reporting through the use of 'unfamiliar terms' and 'false inference' on the part of respondents as they again misinterpret the intention of question (Groves et al., 2009) or search some areas of memory while neglecting others (Schaeffer and Presser, 2003). An example of this in legal need surveys is discussed by Pleasence and Balmer (2011) with regard to discrimination problems. They observed that for the 2006-2009 CSJS discrimination was often misunderstood as referring to insensitive or unpleasant public behaviour. Consequently, discrimination questions were paired with other problem types (such as employment or housing) in subsequent surveys in England and Wales.

\section{Selection of Problems for Data Collection}

Even where problem definitions are consistent between surveys, the methods used to select problems for data collection have not always been the same. This has been an issue as, when multiple problems are reported, surveys have been limited in the number of problems about which full data can be collected.

Unfortunately, different surveys have employed different methods for problem selection, with not all surveys having sought to obtain a representative sample of problems. However, obtaining a representative sample of problems through random or quasi-random selection of problems is not without it disadvantages in this context. The United States Comprehensive Legal Needs Study collected data relating to 5 problems, and so no problems were envisaged with the use of simple randomization. The Canadian surveys collected data relating to 3 problems and limited these to one per category to prevent the data being overwhelmed by the most common problem types. The early English and Welsh Civil and Social Justice surveys employed a weighted random selection method to prevent problem samples (for detailed follow up of single problems) being overwhelmed by the most common problem types. The recent Taiwanese survey collected data for the most recent of multiple problems to minimize "the risk of memory loss" (Chen, Huang and Lin 2012, p.9), although it was recognised that this strategy also involved a risk of problems being more likely to be on-going. In addition, as is explained in the next section, by selecting recent over older problems, selected problems are likely to be less serious. The original Paths to Justice surveys collected data for the second most recent problem identified, as a compromise. 
Table 4: Types of Justiciable Problems Included in Recent Legal Needs Surveys (Where Known)

\begin{tabular}{|c|c|c|c|c|c|c|c|c|c|c|c|c|c|c|c|c|c|c|c|c|c|c|c|c|}
\hline & 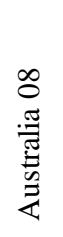 & 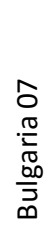 & 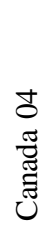 & 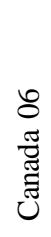 & 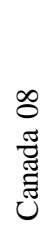 & 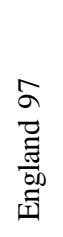 & 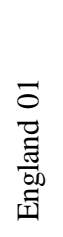 & 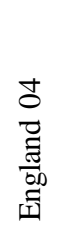 & 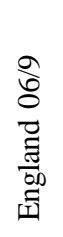 & 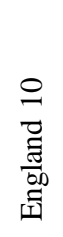 & 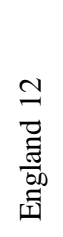 & $\begin{array}{l}8 \\
0 \\
00 \\
0 \\
\forall \\
0 \\
00 \\
0 \\
I\end{array}$ & 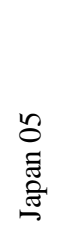 & 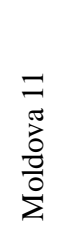 & 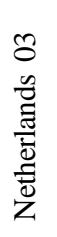 & 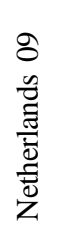 & 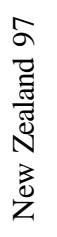 & 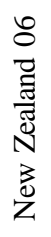 & 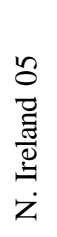 & 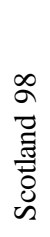 & $\begin{array}{l}\Delta \\
\text {. } \\
. \frac{\pi}{\pi} \\
\frac{\sigma}{\sigma} \\
\frac{0}{n}\end{array}$ & 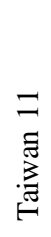 & 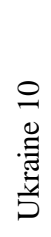 & 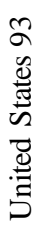 \\
\hline Non-criminal & 0 & 0 & 0 & 0 & 0 & 0 & 0 & 0 & 0 & 0 & 0 & 0 & 0 & 0 & 0 & 0 & 0 & 0 & 0 & 0 & 0 & 0 & 0 & ○ \\
\hline Care (of others) & $\bullet$ & & $\bullet$ & $\bullet$ & $\bullet$ & & & & & & & & $\bullet$ & & & & $\bullet$ & & $\bullet$ & & $\bullet$ & $\bullet$ & & $\bullet$ \\
\hline Children (abduction) & & & $\bullet$ & $\bullet$ & • & - & $\bullet$ & $\bullet$ & $\bullet$ & & & & & & & & & & $\bullet$ & $\bullet$ & - & & & \\
\hline Children (adoption) & - & & $\bullet$ & - & $\bullet$ & & - & - & - & & & & & & $\bullet$ & - & & - & - & & - & & & $\bullet$ \\
\hline Children (care) & - & $\bullet$ & $\bullet$ & $\bullet$ & $\bullet$ & - & $\bullet$ & $\bullet$ & $\bullet$ & - & • & & & - & & & - & $\bullet$ & - & $\bullet$ & $\bullet$ & & $\bullet$ & $\bullet$ \\
\hline Clinical negligence & - & $\bullet$ & $\bullet$ & $\bullet$ & $\bullet$ & - & - & $\bullet$ & - & - & - & - & - & - & $\bullet$ & - & - & 0 & $\bullet$ & $\bullet$ & $\bullet$ & 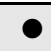 & 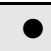 & $\overline{0}$ \\
\hline Consumer & $\bullet$ & $\bullet$ & $\bullet$ & $\bullet$ & $\bullet$ & $\bullet$ & $\bullet$ & $\bullet$ & $\bullet$ & $\bullet$ & $\bullet$ & $\bullet$ & $\bullet$ & $\bullet$ & $\bullet$ & $\bullet$ & $\bullet$ & $\bullet$ & - & $\bullet$ & $\bullet$ & $\bullet$ & $\bullet$ & $\bullet$ \\
\hline Defamation & & & & & & & & & & & & - & - & & $\bullet$ & - & & & & $\bullet$ & & $\bullet$ & & $\bullet$ \\
\hline Discrimination & - & $\bullet$ & $\bullet$ & $\bullet$ & $\bullet$ & $\bullet$ & $\bullet$ & $\bullet$ & $\bullet$ & $\bullet$ & • & $\bullet$ & $\bullet$ & • & $\bullet$ & $\bullet$ & - & & $\bullet$ & $\bullet$ & • & & • & $\bullet$ \\
\hline Domestic violence & & $\bullet$ & & & & - & - & • & - & - & - & - & & - & $\bullet$ & - & - & - & - & $\bullet$ & $\bullet$ & $\bullet$ & - & $\bullet$ \\
\hline Education & $\bullet$ & $\bullet$ & $\bullet$ & & & $\bullet$ & $\bullet$ & $\bullet$ & $\bullet$ & $\bullet$ & $\bullet$ & $\bullet$ & & $\bullet$ & $\bullet$ & $\bullet$ & $\bullet$ & $\bullet$ & $\bullet$ & $\bullet$ & & & $\bullet$ & $\bullet$ \\
\hline Employment & $\bullet$ & $\bullet$ & $\bullet$ & $\bullet$ & $\bullet$ & $\bullet$ & $\bullet$ & $\bullet$ & $\bullet$ & $\bullet$ & $\bullet$ & $\bullet$ & $\bullet$ & $\bullet$ & $\bullet$ & $\bullet$ & $\bullet$ & $\bullet$ & $\bullet$ & $\bullet$ & $\bullet$ & $\bullet$ & $\bullet$ & $\bullet$ \\
\hline Family (divorce) & $\bullet$ & $\bullet$ & $\bullet$ & $\bullet$ & $\bullet$ & $\bullet$ & $\bullet$ & $\bullet$ & $\bullet$ & $\bullet$ & $\bullet$ & $\bullet$ & $\bullet$ & $\bullet$ & - & $\bullet$ & $\bullet$ & $\bullet$ & $\bullet$ & $\bullet$ & $\bullet$ & $\bullet$ & $\bullet$ & $\bullet$ \\
\hline Family (ancillary issues) & $\bullet$ & $\bullet$ & $\bullet$ & $\bullet$ & $\bullet$ & $\bullet$ & - & $\bullet$ & $\bullet$ & $\bullet$ & $\bullet$ & $\bullet$ & $\bullet$ & $\bullet$ & $\bullet$ & $\bullet$ & $\bullet$ & $\bullet$ & $\bullet$ & $\bullet$ & $\bullet$ & $\bullet$ & $\bullet$ & $\bullet$ \\
\hline Govt./administrative & $\bullet$ & $\bullet$ & $\bullet$ & $\bullet$ & $\bullet$ & $\bullet$ & - & - & - & - & - & - & - & - & $\bullet$ & - & - & - & - & $\bullet$ & $\bullet$ & • & - & $\bullet$ \\
\hline Housing (neighbours) & $\bullet$ & $\bullet$ & & & $\bullet$ & $\bullet$ & - & $\bullet$ & $\bullet$ & $\bullet$ & $\bullet$ & $\bullet$ & $\bullet$ & $\bullet$ & $\bullet$ & $\bullet$ & $\bullet$ & $\bullet$ & $\bullet$ & $\bullet$ & $\bullet$ & • & $\bullet$ & $\bullet$ \\
\hline Housing (homelessness) & & & & & & & $\bullet$ & $\bullet$ & $\bullet$ & & & $\bullet$ & & & & & & $\bullet$ & - & & & & & \\
\hline Housing (rented) & $\bullet$ & $\bullet$ & $\bullet$ & $\bullet$ & $\bullet$ & $\bullet$ & $\bullet$ & $\bullet$ & $\bullet$ & $\bullet$ & $\bullet$ & $\bullet$ & $\bullet$ & $\bullet$ & $\bullet$ & - & $\bullet$ & $\bullet$ & $\bullet$ & $\bullet$ & $\bullet$ & $\bullet$ & - & $\bullet$ \\
\hline Housing (owned) & $\bullet$ & $\bullet$ & $\bullet$ & - & $\bullet$ & - & $\bullet$ & $\bullet$ & $\bullet$ & $\bullet$ & $\bullet$ & $\bullet$ & $\bullet$ & $\bullet$ & $\bullet$ & - & 0 & $\bullet$ & ○ & $\bullet$ & $\bullet$ & ○ & $\bullet$ & $\bullet$ \\
\hline Housing (renting out) & $\bullet$ & $\bullet$ & & & & $\bullet$ & & & & & & $\bullet$ & $\bullet$ & $\bullet$ & $\bullet$ & $\bullet$ & $\bullet$ & $\bullet$ & & $\bullet$ & $\bullet$ & $\bullet$ & 0 & $\bullet$ \\
\hline Immigration & & & $\bullet$ & $\bullet$ & $\bullet$ & $\bullet$ & - & $\bullet$ & $\bullet$ & & & $\bullet$ & & $\bullet$ & $\bullet$ & $\bullet$ & $\bullet$ & $\bullet$ & $\bullet$ & $\bullet$ & $\bullet$ & & $\bullet$ & $\bullet$ \\
\hline
\end{tabular}




\begin{tabular}{|c|c|c|c|c|c|c|c|c|c|c|c|c|c|c|c|c|c|c|c|c|c|c|c|c|}
\hline Mental health & ? & & ? & - & - & & - & $\bullet$ & - & - & - & - & & & & & & & - & & & & & $\bullet$ \\
\hline Money (Debt) & $\bullet$ & $\bullet$ & $\bullet$ & $\bullet$ & $\bullet$ & $\bullet$ & $\bullet$ & $\bullet$ & $\bullet$ & $\bullet$ & $\bullet$ & $\bullet$ & $\bullet$ & $\bullet$ & $\bullet$ & $\bullet$ & $\bullet$ & $\bullet$ & $\bullet$ & $\bullet$ & $\bullet$ & $\bullet$ & $\bullet$ & $\bullet$ \\
\hline Money (Fin. services) & $\bullet$ & $\bullet$ & $*$ & $*$ & $\bullet$ & $\bullet$ & $\bullet$ & $\bullet$ & - & - & $\bullet$ & 0 & $\bullet$ & $\bullet$ & $\bullet$ & $\bullet$ & $\bullet$ & $\bullet$ & • & $\bullet$ & - & $\bullet$ & ๑ & 0 \\
\hline Personal injury & $\bullet$ & $\bullet$ & • & • & • & - & - & $\bullet$ & $\bullet$ & $\bullet$ & • & - & - & - & - & - & - & & $\bullet$ & - & - & - & - & $\bullet$ \\
\hline Police (treatment by) & $\bullet$ & $\bullet$ & $\bullet$ & $\bullet$ & $\bullet$ & $\bullet$ & $\bullet$ & $\bullet$ & $\bullet$ & $\bullet$ & $\bullet$ & - & & - & $\bullet$ & - & & & $\bullet$ & - & - & 0 & - & $\bullet$ \\
\hline Social services (access) & & $\bullet$ & • & $\bullet$ & $\bullet$ & & & & & & & & $\bullet$ & - & & & & & $\bullet$ & & & & $\bullet$ & 0 \\
\hline Welfare benefits & - & - & - & - & $\bullet$ & - & - & $\bullet$ & $\bullet$ & $\bullet$ & - & & - & - & $\bullet$ & - & - & - & $\bullet$ & - & & - & - & - \\
\hline Wills and probate & - & & - & $\bullet$ & - & $\bullet$ & & & & & & $\bullet$ & - & & $\bullet$ & - & - & - & & - & - & - & & $\bullet$ \\
\hline Other & $\bullet$ & & $\bullet$ & - & $\bullet$ & - & $\bullet$ & & & & & $\bullet$ & $\bullet$ & & & & - & - & & $\bullet$ & $\bullet$ & - & & \\
\hline Criminal & 0 & & & & & & & 0 & 0 & 0 & 0 & 0 & & & & & 0 & 0 & & & 0 & & & \\
\hline Criminal (victim) & $\bullet$ & & $*$ & $*$ & $*$ & & & $\bullet$ & $\bullet$ & $\bullet$ & $\bullet$ & & & & & & $\bullet$ & $\bullet$ & & & $\bullet$ & & & \\
\hline Criminal (offender) & & & • & & & & & $\bullet$ & & $\bullet$ & $\bullet$ & $* *$ & & & & & • & - & & & - & & & \\
\hline Business & 0 & & & & & & & & & & & & & & & & & & & & 0 & & & 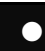 \\
\hline
\end{tabular}

Notes: * Criminal injuries compensation. ** Traffic and littering offences. 
For some surveys, though, concerns about the methodological purity of problem selection have clearly given way to pragmatic concerns about the incorporation of good numbers of problems involving the use of legal services or processes. So, for example, the 2005 and 2006 Japanese surveys, 2006 New Zealand survey and 2008 Australian survey all collected data for the most serious problems faced. As has been repeatedly shown (e.g. Pleasence et al 2004a, Dignan 2006, Kritzer 2008, Pleasence, Balmer and Reimers 2011, Chen et al 2012, Pleasence and Balmer 2012), advice, including legal advice, becomes more likely as problems become more serious, and so problems about which data was obtained in these surveys will (as intended) be more likely to have involved advice, legal advice, and legal process (e.g. Pleasence et al 2004a). This makes comparison with findings from more representative samples difficult.

\section{6. $\quad$ Reference Period}

The surveys listed in Table 2 have reference periods ranging from 1 to 6 years. Evidently, changing a reference period will have the effect of changing the number of justiciable problems that are reported.

Unfortunately, recall of events is not consistent going back through time, with a general rule that failure to recall becomes more of a problem the further back in time events have occurred (Sudman and Bradburn 1973). This means that differing reference periods pose a significant challenge to comparative analysis. Frequency of recalled events cannot be simply divided by time to produce a standardised figure. On top of this, memories of different types of episode do not always exhibit similar "forgetting curves" (i.e. patterns of recall error over time) (Tourangeau et al 2000, p.84). ${ }^{21}$ This phenomenon is well illustrated, in the context of justiciable problems, by Pleasence et al (2009). Their analysis of the pattern of reporting of problems in the 2001, 2004 and 2006-9 English and Welsh surveys demonstrated a sharp contrast between well-remembered divorces (!) and poorly remembered consumer problems.

Likely as a consequence of recall errors, the Hong Kong survey, which asked respondents to recall events from 1 year, 5 years and over the entire life course, recorded (evidently disproportionate) respective problem incidence rates of $19 \%, 32 \%$ and $40 \%$.

The effect of recall errors will not only affect reported problem incidence. The greater the reference period, the higher the proportion of more salient problems that will be reported. This, in turn, will impact on the pattern of problem resolution strategies reported. As noted above, advice, including legal advice, becomes more likely as problems become more serious. Thus, it can be expected that as a survey reference period increases, so too will the proportion of reported problems about which advice is obtained.

\section{Data Structure and Units of Analys is}

A further obstacle to the simple comparison of findings of legal need surveys is differences in data structure and units of analysis. The first of these is really an aspect of sampling, but we deal with it hear as it has a direct bearing on units of analysis.

As can be seen from Table 2, the great majority of the surveys listed are of individuals. Indeed, one of the most patent features of the Paths to Justice tradition of surveys is that the constituent surveys tend to be concerned with individual experience. This contrasts with the, largely isolated (e.g. Access to Justice Study Committee 2007)

\footnotetext{
21 There seem to be several factors underlying differences in forgetting curves, but in general terms, as Tourangeau et al have commented (p.92), “... we are less likely to forget important events than unimportant ones; we are more likely to notice them in the first place and to discuss and think about them afterward. Thus, important events have the advantage of both more elaborate initial encoding and greater rehearsal after the fact; both factors probably contribute to greater retrievability."
} 
tradition of (generally sub-national) legal need surveys in the United States, which have taken the household (rather than the person) as the unit of analysis. All but one of the 17 contemporary United States national and state surveys has adopted this approach.

As shown in Table 2, the Canadian surveys have fallen in-between the two traditions. In the Canadian surveys, questions about problem experience were asked about respondents and their life partners together. This is likely to have had a significant impact on reported problem incidence, with incidence inflated through the greater opportunity for problems to be recorded against couples, as opposed to individuals. By way of illustration, if data from the 2006-9 English and Welsh Civil and Social Justice Survey are re-analysed, aggregating the reported experience of married/cohabiting respondents, then problem incidence increases from $36 \%$ to $48 \%$. Similar to this, the 1997 New Zealand survey, the 2005 Japanese survey and the 2011 Taiwanese surveys all asked about problems experienced by respondents and their children ${ }^{22}$ together. Again, this is likely to inflate recorded incidence.

It might be assumed that the collection of individual data is preferable to the collection of household or combined partner data, as individual data can be aggregated to the household level. However, there are distinct benefits to the collection of household data. Aside from cost advantages, ${ }^{23}$ household data may more accurately reflect the experience of shared problems (i.e. those that are faced by families together), the linking (and counting) of which can be problematic in individual surveys. But, as not all problems within households are shared, household data collection is more likely to miss problems experienced by household members other than the respondent. It will be less reliable in relation to such problems when they are identified.

Individual data collection within a household based sample frame, such as in the English and Welsh, Hong Kong and Scottish surveys, also allows for data analysis at multiple levels of aggregation and the investigation of household effects (e.g. Pleasence et al 2004b). However, this form of data structure also raises obstacles to the comparison of the published results of inferential statistical analyses. Some reported analyses of data from the Paths to Justice surveys (Genn 1999, Genn and Paterson 2001) and first Civil and Social Justice Survey (Pleasence et al 2004a) did not account for this data structure. Failure to account for the hierarchical (household) structure will not recognise the existence of clustering, and will generally result in the underestimation of standard errors associated with model coefficients (e.g. Goldstein 2011, Rasbash et al. 2012). ${ }^{24}$ Moreover, the published Hong Kong survey findings (Asia Consulting Group and Policy 21 2008) do not extend beyond basic descriptive statistics. ${ }^{25}$

\section{C. $\quad$ The Impact of Legal Needs Survey Design: Experimental Evidence}

We now turn from detailing differences in the methods employed by recent legal needs surveys, and discussing their possible impact in the context of the survey methodology literature, to exploring the impact of particular survey design differences through a series of experiments. These experiments were conducted as part of the development work for the

\footnotetext{
${ }^{22}$ In the case of New Zealand, this extended to children still in the case of the respondent. In the case of Japan and Taiwan children were included up to the age of 19.

23 The experience of a greater number of individuals can be covered than the number of interviews conducted.

${ }^{24}$ Conversely, in aggregate analyses (e.g. at a household level), failure to account for structure would make it unclear how to interpret relationships (see Woodhouse and Goldstein, 1989 for an empirical demonstration). There is also an increased interest in statistical survey analysis methods for complex samples which control for aspects of design, including clustering and stratification (e.g. see Heeringa et al 2010), though there is little evidence of such techniques being incorporated into the analysis of legal need survey data to date.

${ }^{25}$ In addition to the above, where multiple problems experienced by the same person are included in problem level analyses, the fact that an individual links the problems should also be accounted for.
} 
English and Welsh Civil and Social Justice Panel Survey, and were designed for the purpose of demonstrating whether particular differences impact significantly on findings. Specifically, in relation to problem prevalence, we tested the impact of survey reference period (problems in the past year vs. problems in the past three years), 'legal' framing (whether or not problems of interest are introduced as 'legal' or not) detail of problem description (detailed problem subcategories vs. single problem type) and the inclusion of a ('difficult to solve') triviality filter. Also, in relation to advice seeking and the use of formal processes, we tested the impact of presenting advisers/processes used in a single list, rather than within multiple adviser/process specific questions. Details of the structure of the five experiments are set out further below.

\section{Methods}

Our experiments were conducted within two Internet surveys of 625 and 986 people resident in the United Kingdom, aged between 20 and 66 years old. The surveys were programmed using Adobe Flash and administered to members of the ipoints ${ }^{\mathrm{TM}}$ online reward scheme, an access pane ${ }^{26}$ that extends to 950,000 United Kingdom residents. The surveys were run during March 2009 and May/June 2010 respectively. ${ }^{27}$ A sample of ipoints ${ }^{\mathrm{TM}}$ members received invitations to participate in a survey, ${ }^{28}$ accessed via a link. The survey was closed once the required number of respondents completed the survey. The 'participation rate' (Callegaro and DiSorga 2008), or response rate within the panel sample, was likely around $25 \%,{ }^{29}$ though no definitive figure is available to us. ${ }^{30}$

Online surveys were chosen in this instance as they represented best value for money (with the cost around $1 \%$ of a probability face-to-face survey) in the context of English and Welsh Civil and Social Justice Panel Survey development. This was particularly so, given that the primary focus of our experiments was on internal, rather than external, validity. While surveys of access panels members (not being probability surveys) are limited in their external validity, ${ }^{31}$ as our main concern was to identify the existence of causal relationships between design changes and survey responses, along with an idea of the potential magnitude of impacts, we considered the use of a broad based access panel appropriate. As the American Association for Public Opinion Research (AAPOR) concluded in its research synthesis and report on online panels (Baker et al 2010, p.714):

Not all research is intended to produce precise estimates of population values, and so there may be survey purposes and topics where the generally lower cost and unique properties of Web data collection are an acceptable alternative to traditional probability-based methods.

This conclusion of the AAPOR has particular application in the case of the current experiments, as even had they been conducted using probability samples in the United Kingdom, the results could only have been inferred to a particular mode of surveys of the

\footnotetext{
${ }^{26}$ An access panel is set of individuals who have expressed a willingness to participate in survey research. Access panels can be compiled in various ways. The ipoints ${ }^{\mathrm{TM}}$ panel is made up of members of the ipoints ${ }^{\mathrm{TM}}$ online reward scheme - which provides cash-back type rewards to members shopping within a particular online environment - who have agreed to participate in online research in return for ipoints ${ }^{\mathrm{TM}}$. As Callegaro et al (2014) have detailed, access panels are built "through non-probability methods such as snowball sampling, bannerads, direct enrollment, and other strategies to obtain large samples at low cost."

${ }^{26}$ In 2009, 70\% of UK households had internet access (ONS 2009).

${ }^{27}$ In 2009, 70\% of UK households had internet access (ONS 2009).

${ }^{28}$ No details of the subject matter or sponsor were provided.

${ }^{29}$ According to ipoints ${ }^{\mathrm{TM}}$ in correspondence.

30 The use of pre-specified sample sizes and access panels present a challenge to the reporting of response rates in any traditional form (see, for example, Baker et al 2010).

${ }^{31}$ For a recent discussion of data quality and online panels, see Callegaro et al (2014).
} 
United Kingdom population. Thus, to have explored, in a comprehensively externally valid manner, the impact of design differences between recent national legal needs surveys worldwide would have required the conduct of a whole range of probability surveys, in the different jurisdictions and using different modes of delivery; a task that would have been prohibitively expensive and vastly disproportionate to our quite narrowly defined research objectives. As Kish (1987, p.1) has observed, "statistical designs always involve compromises between the desirable and possible."

Of course, a concern of those utilising access panels is the relevance of findings to real world populations (as distinct from providing population estimates). So, wanting to be confident that our findings are relevant (as distinct from representative) beyond a narrowly defined and anomalous population group, we analysed the composition of the samples utilised to ensure their heterogeneity. While the samples are limited to those with Internet access, and only included respondents aged between 19 and 66 years, they are otherwise fairly diverse in make-up. Compared to the UK working age population, the samples have a moderately higher percentage of persons who are male, aged over 34, unmarried, university educated, and long-term ill or disabled. ${ }^{32}$

The larger survey (of 986 respondents) asked respondents about the experience of ten types of justiciable problem, as well as where they sought advice and whether any formal processes were used (e.g. court, mediation etc.). The ten problem types are present in the majority of legal need surveys, and comprised problems concerning neighbours, rented housing, owned housing, employment, welfare benefits, consumer issues, debt, divorce, relationship breakdown and negligent accidents/clinical negligence. This survey contained four of the five experiments; those relating to the reference period, 'legal' framing of problems, amount of detail in problem description (all with relation to problem prevalence) and the use of lists compared to multiple questions to obtain data (with relation to use of advisers and processes).

The smaller survey (of 625 respondents) asked respondents about the experience of three common problem types (consumer, employment and neighbours issues), and contained the experiment relating to the phrasing of problem identification questions, and whether or not problems were introduced as 'difficult to solve'. Further details of the five experiments are set out below.

\section{A. Experiments Conducted}

\section{Experiment 1 - Reference Period and Problem Prevalence}

When problems or disputes were introduced in the survey, respondents were randomly allocated into a one year (version 1) or a three year reference period (version 2). The difference was presented in the preamble to problem identification as shown below, and all saw the subsequent problems in the same order.

Version 1- one year reference period (for an example interview date of August 2012)

The following questions ask about different kinds of problems or disputes you might have experienced in recent years. Please only include problems or disputes you have had yourself, not problems which you have experienced as part of your business. Only problems that you have

\footnotetext{
32 Figures for the smaller sample were $56 \%$ male, $80 \%$ aged over $34,50 \%$ unmarried, $71 \%$ employed (full- or part-time), and $46 \%$ university educated. Figures for the larger sample were $54 \%$ male, $77 \%$ aged over 34 , $70 \%$ employed (full- or part-time), $46 \%$ university educated, and 22\% long-term ill/disabled. 2011 census figures for the population aged 20 to 64 were $50 \%$ male, $66 \%$ aged over 34, 46\% unmarried, $72 \%$ employed (age 16-49), 32\% university educated, and 13\% long-term ill/disabled.
} 
experienced since (August 2011) should be included, including any which started before then but were still going on in (August 2011).

Version 2 - three year reference period (for an example interview date of August 2012)

The following questions ask about different kinds of problems or disputes you might have experienced in recent years. Please only include problems or disputes you have had yourself, not problems which you have experienced as part of your business. Only problems that you have experienced since (August 2009) should be included, including any which started before then but were still going on in (August 2009).

2. $\quad$ Experiment 2 - 'Legal' Framing and Problem Prevalence

When problems or disputes were introduced in the survey, respondents were randomly allocated into a group where problems were introduced without any reference to them being 'legal' (version 1) or a group referring to 'legal problems' (version 2). As with the reference period manipulation above (experiment 1), the 'legal' framing experiment was included in the general preamble to the problem identification questions, rather than individual problem questions. Again, all saw the subsequent problems in the same order.

Version 1- 'legal' framing excluded

The following questions ask about different kinds of problems or disputes you might have experienced in recent years. Please only include problems or disputes you have had yourself, not problems which you have experienced as part of your business. Only problems that you have experienced since (insert date) should be included, including any which started before then but were still going on in (insert date).

Version 2 - 'legal framing included

The following questions ask about different kinds of legal problems or disputes you might have experienced in recent years. Please only include problems or disputes you have had yourself, not problems which you have experienced as part of your business. Only problems that you have experienced since (insert date) should be included, including any which started before then but were still going on in (insert date).

3. Experiment 3-Amount of Detail in Problem Description and Problem Prevalence Each of the ten problem types presented to respondents were individually randomised into a group where they were presented with no detail and reference only to the general problem type (version 1) or a group with detailed problem subcategories (version 2).

Version 1- no detail example

Since (insert date), have you experienced any problems or disputes to do with renting your home 
Version 2 - example with detail provided

Since (August 2011), have you experienced any problems or dis putes to do with renting your

home of one of the types detailed below?

\section{Condition of accommodation}

- $\quad$ Unsafe or unsuitable living conditions

\section{Dealing with your landlord}

- $\quad$ Difficulty getting a deposit back

- Difficulty getting the landlord to do repairs or provide other services under the terms of your lease

- $\quad$ Problems agreeing on the terms of your lease

- $\quad$ Getting your landlord to provide a written lease or tenancy agreement

- Harassment by your landlord

- $\quad$ Eviction or threat of eviction (excluding for non-payment of rent)

4. Experiment 4 - Lists vs. Multiple Questions in Use of Advisers and Processes Where respondents had one or more justiciable problem, a random problem was selected to progress to questions regarding advice seeking and use of formal processes. These problems were then randomised into two groups. In the first, advisers and processes were presented as a single multiple-response list (version 1), with the order fixed. In the second they were presented as individual questions for each option (version 2), and again advisers/processes were always presented in the same order. Note that version 2 shows the general format for the first two questions/options only. This was followed by a further eight questions relating to each of the options in version 1 (though excluding "none of these').

Version 1- advice seeking and processes in list form

Thinking again of the same problem, did any of the following things happen as part of the problem or sorting the problem out?

1. You sought help from a solicitor

2. You sought help from an advice agency (e.g. Citizens Advice Bureau, National Debtline)

3. You sought help from the police

4. You sought help from a regulator or ombudsman (e.g. Ofcom, Financial Ombudsman Service)

5. You sought help from another formal adviser

6. You or the other side contacted, or were contacted by, a court, tribunal or formal appeals service

7. Conciliation, mediation or arbitration was arranged with an independent conciliator, mediator or arbitrator

8. A court, tribunal or formal appeals service hearing took place

9. You attended a court, tribunal or formal appeals service hearing

10. A court or tribunal made a decision about the problem

11. None of these 
Version 2- advice seeking and processes as multiple questions (two examples)

And thinking again of the same problem ...

Did you seek help from a solicitor?

Did you seek help from an advice agency, such as a Citizens Advice Bureau or National Debtline?

5. Experiment 5 - 'Difficult to Solve' Phrasing in Problem Prevalence

Using the smaller survey of 625 respondents, participants were asked about their experience of consumer, employment and neighbours problems over the past three years. Respondents were randomly allocated into a group where problem identification questions referred to problems that were 'difficult to solve' (version 1) or a group where this phrase was removed (version 2). All participants saw the same problems in the same order.

Version 1- example with 'difficult to solve phrasing'

Since (insert date), have you experienced any problems or disputes to do with anti-s ocial behaviour by neighbours that were difficult to solve (such as regular excessive noise, threats harassment or violence aimed at you, or damage to your property)?

Version 2-example without 'difficult to solve phrasing

Since (insert date), have you experienced any problems or disputes to do with anti-s ocial

behaviour by neighbours (such as regular excessive noise, threats harassment or violence aimed at you, or damage to your property)?

\section{B. Analysis}

We fitted four statistical models to explore the relationship between the five experimental manipulations and problem prevalence or advice seeking/use of formal processes.

First, using the larger survey (986 respondents) a binary logistic regression model was fitted to examine prevalence of any problem (of the ten types presented), on the basis of survey reference period, 'legal' framing of problems and whether each of the problem types was presented in short or long (detailed) form (experiments 1-3). Second, we fitted a multivariate binary logistic regression model, simultaneously including all of the ten problem types as response variables. Again, survey reference period, 'legal' framing of problems and whether each of the problem types was presented in short or long (detailed) form were included as predictors (experiments 1-3). Third, a further multivariate model was fitted with whether or not respondents used each adviser type and process as response variables and whether presentation of advisers/processes was in a single list or in multiple questions as a predictor (experiment 4). Finally, using the smaller survey (625 respondents) a further multivariate logit model was fitted, with each of the three problem types as response variables and whether or not 'difficult to solve' was used in problem identification questions as a predictor (experiment 5). This was followed by a simple chisquared test to explore the relationship between the use of 'difficult to solve' in problem phrasing and any of the three types of problem.

Multivariate models were fitted using MLwiN (Rasbash et al., 2009a) with multivariate response data conveniently incorporated by creating an extra level below the original respondent level units, yielding responses (prevalence of each problem) nested within respondents (e.g. see Goldstein, 2011; Rasbash et al., 2009b). Each multivariate model also produces a respondent level covariance matrix. In the case of problem prevalence this shows the tendency of problems types to occur in combination. 


\section{Results}

A. Experiments 1, 2 and 3 - Reference Period, 'Legal' Framing, Detail of Problem Description in Problem Prevalence

Table 5 shows binary logistic regression output, modelling whether or not respondents reported any problem, on the basis of survey reference period, 'legal' framing of problems and whether each of the problem types was presented in short or long (detailed) form.

Table 5: Binary Logistic Regression of Prevalence of 'Any Problem' on the Basis of Reference Period, Legal Framing and Detail of Problem Descriptions (Significant Terms (p $<0.05)$ in Bold).

\begin{tabular}{|l|l|c|c|}
\hline & & B & S.E. \\
\hline Constant & & $\mathbf{0 . 5 9}$ & $\mathbf{0 . 2 4}$ \\
\hline Reference period & One year & 0.00 & - \\
\hline & Three years & 0.23 & 0.13 \\
\hline Framing of problems & Not described as legal & 0.00 & - \\
\hline & Described as legal & $\mathbf{- 0 . 5 0}$ & $\mathbf{0 . 1 3}$ \\
\hline Detailed problem description* & Rented housing & -0.20 & 0.13 \\
\hline & Owned housing & 0.04 & 0.13 \\
\hline & Employment & -0.17 & 0.13 \\
\hline & Welfare benefits & 0.01 & 0.13 \\
\hline & Consumer & 0.04 & 0.13 \\
\hline & Debt & 0.07 & 0.13 \\
\hline & Divorce & 0.003 & 0.13 \\
\hline & Relationship breakdown & -0.11 & 0.13 \\
\hline & Accidents/clinical negligence & -0.06 & 0.13 \\
\hline & Neighbours & 0.04 & 0.13 \\
\hline
\end{tabular}

Notes: *Compared to simple 'problem type only' description with no problem subcategories

Use of a three year survey reference period as opposed to a one year period (experiment 1) was related to an increase in problem prevalence, though the difference was fairly modest and non-significant ( Wald $_{1}=2.99, \mathrm{p}=0.084$ ). In percentage terms, 59.0 per cent reported one or more problem where a three year survey reference period was used, compared to 53.8 per cent for a one year reference period.

In contrast, framing problems as 'legal' (experiment 2) was associated with a significant reduction in problem prevalence when compared to introducing problems without any reference to them being legal (Wald $1=14.55, \mathrm{p}<0.001$ ). Where problems were introduced as legal, 50.8 per cent reported one or more problem, with this rising to 62.6 per cent where they were not.

Whether or not detailed problem descriptions were used (as opposed to problem types only) (experiment 3) had little relationship to overall problem prevalence, with none of the terms significant. If all problems are combined in a simplified model (i.e. rather than analysing individual problem types), with problems nested within respondents, whether or not a detailed problem description remains non-significant $\left(\chi^{2}{ }_{1}=2.38, p=0.12\right)$. In percentage terms, problem prevalence for an average problem might be expected to increase from 6.6 to 7.6 per cent. However, in the case of detail of problem description, there is limited scope for differences for individual problems to influence the overall prevalence of 'any problem', particularly for less common problem types. As a result, the association between prevalence and detail of problem description is more appropriately examined at the individual problem type level, since detail/lack of detail was randomized at the individual problem, rather than the respondent level. Problem type level analysis is 
shown in the model in Table 6 below, presenting multivariate binary logistic regression model output, simultaneously modelling the ten problem types as response variables, on the basis of survey reference period, 'legal' framing of problems and whether each of the problem types was presented in short or long (detailed) form. The covariance matrix associated with the model in Table 6 is shown in Table 7.

Table 6: Multivariate Binary Logistic Regression of Prevalence of Each Problem Type on the Basis of Reference Period, 'Legal' Framing of Problems and Detail of Problem Description (Significant Terms ( $\mathrm{p}$ 0.05) in Bold).

\begin{tabular}{|l|c|c|c|c|c|c|c|c|}
\hline Response variables & \multicolumn{2}{|c|}{ Constant } & \multicolumn{2}{|c|}{$\begin{array}{c}\text { Length of } \\
\text { description } \\
\text { Detailed }^{*}\end{array}$} & \multicolumn{2}{c|}{$\begin{array}{c}\text { Reference } \\
\text { period } \\
\text { Three years* }\end{array}$} & \multicolumn{2}{|c|}{$\begin{array}{c}\text { Legal framing } \\
\text { Legal*** }\end{array}$} \\
\hline Problem type & B & SE & B & SE & B & SE & B & SE \\
\hline Rented housing & $\mathbf{- 2 . 8 0}$ & $\mathbf{0 . 2 7}$ & 0.20 & 0.25 & -0.14 & 0.27 & 0.05 & 0.27 \\
\hline Owned housing & $\mathbf{- 2 . 6 8}$ & $\mathbf{0 . 2 6}$ & 0.41 & 0.25 & -0.01 & 0.26 & -0.48 & 0.26 \\
\hline Employment & $\mathbf{- 1 . 7 4}$ & $\mathbf{0 . 1 8}$ & 0.29 & 0.17 & 0.00 & 0.18 & -0.26 & 0.18 \\
\hline Welfare benefits & $\mathbf{- 2 . 6 2}$ & $\mathbf{0 . 2 4}$ & 0.28 & 0.21 & 0.01 & 0.23 & 0.19 & 0.23 \\
\hline Consumer & $\mathbf{- 0 . 6 1}$ & $\mathbf{0 . 1 3}$ & 0.23 & 0.13 & 0.13 & 0.14 & $\mathbf{- 0 . 5 9}$ & $\mathbf{0 . 1 4}$ \\
\hline Debt & $\mathbf{- 2 . 1 5}$ & $\mathbf{0 . 2 2}$ & 0.21 & 0.20 & $\mathbf{- 0 . 4 8}$ & $\mathbf{0 . 2 2}$ & 0.10 & 0.21 \\
\hline Divorce & $\mathbf{- 3 . 6 7}$ & $\mathbf{0 . 4 0}$ & - & - & 0.20 & 0.41 & 0.09 & 0.41 \\
\hline Relationship & $\mathbf{- 3 . 1 6}$ & $\mathbf{0 . 3 5}$ & -0.63 & 0.35 & 0.31 & 0.38 & -0.44 & 0.38 \\
\hline Neg. Accidents & $\mathbf{- 3 . 9 9}$ & $\mathbf{0 . 4 0}$ & - & - & $\mathbf{0 . 7 7}$ & $\mathbf{0 . 3 6}$ & 0.08 & 0.34 \\
\hline Neighbours & $\mathbf{- 1 . 1 2}$ & $\mathbf{0 . 1 5}$ & 0.08 & 0.15 & 0.01 & 0.16 & $\mathbf{- 0 . 5 8}$ & $\mathbf{0 . 1 6}$ \\
\hline
\end{tabular}

Notes: Compared to the reference categories *'short', **'one year' and, ***'no use of legal'

Table 7: Person-Level Covariance Matrix Associated With the Model in Table $2^{33}$

\begin{tabular}{|c|c|c|c|c|c|c|c|c|c|}
\hline & $\begin{array}{l}0 \\
.0 \\
0 \\
0 \\
0 \\
0 \\
0 \\
0 \\
0 \\
0 \\
\simeq\end{array}$ & 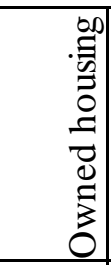 & 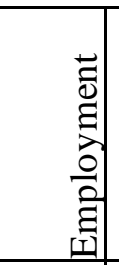 & $\begin{array}{l}0 \\
0 \\
0 \\
0 \\
0 \\
\oplus\end{array}$ & $\begin{array}{c}\overline{0} \\
\vdots \\
\vdots \\
\vdots \\
0 \\
0\end{array}$ & $\begin{array}{l}\overrightarrow{0} \\
0 \\
0\end{array}$ & $\begin{array}{l}0 \\
0 \\
0 \\
: \\
0 \\
0\end{array}$ & 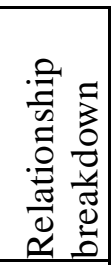 & 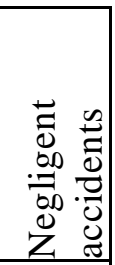 \\
\hline Owned housing & 0.15 & & & & & & & & \\
\hline Employment & 0.13 & 0.17 & & & & & & & \\
\hline Benefits & 0.26 & 0.15 & 0.15 & & & & & & \\
\hline Consumer & 0.10 & 0.17 & 0.17 & 0.12 & & & & & \\
\hline Debt & 0.18 & 0.11 & 0.20 & 0.27 & 0.14 & & & & \\
\hline Divorce & 0.07 & 0.10 & 0.05 & 0.10 & 0.06 & 0.11 & & & \\
\hline Rel. b'down & 0.20 & 0.12 & 0.09 & 0.13 & 0.06 & 0.13 & 0.40 & & \\
\hline Neg. accidents & 0.19 & 0.10 & 0.12 & 0.16 & 0.03 & 0.17 & 0.12 & 0.19 & \\
\hline Neighbours & 0.21 & 0.17 & 0.19 & 0.18 & 0.19 & 0.13 & 0.10 & 0.10 & 0.09 \\
\hline
\end{tabular}

As can be seen in Table 6, detailed problem descriptions were related to increases in the likelihood of all but two problem types (experiment 3), though none of the differences were statistically significant. Increases for consumer (testing the model term; $\left.\chi^{2}{ }_{1}=3.10, p=0.078\right)$ and employment problems $\left(\chi^{2}{ }_{1}=2.82, p=0.098\right)$ were closest to significance, though both fell short. Conversely, detailed descriptions for problems

\footnotetext{
${ }^{33}$ Larger positive terms in the covariance matrix for benefits and rented hous ing problems, debt and benefits problems, neighbours and renting problems and particularly divorce and problems ancillary to relationship breakdown in Table 3 showed that these problems were particularly likely to occur in combination.
} 
ancillary to relationship breakdown were related to a reduction in incidence, though again, this fell short of statistical significance $\left(\chi^{2}{ }_{1}=3.25, \mathrm{p}=0.071\right)$.

In the problem level model, use of a three year as opposed to a one year reference period (experiment 1) made little or no difference to the prevalence of the majority of problem types. The only exceptions were accidents/negligence, where use of a three year reference period related to a significant increase in prevalence $\left(\chi^{2}{ }_{1}=4.70, \mathrm{p}=0.030 ; 2.4 \%\right.$ vs. $5.1 \%$ ) and debt, where interestingly, a three year reference period related to a decrease in prevalence $\left(\chi^{2} 1=4.84, \mathrm{p}=0.028 ; 12.1 \%\right.$ vs. $\left.7.8 \%\right)$.

Finally, framing problems as 'legal' (experiment 2) was related to a significant reduction in the prevalence of consumer $\left(\chi^{2}{ }_{1}=18.26, \mathrm{p}<0.001 ; 39.4 \%\right.$ vs. $\left.26.6 \%\right)$ and neighbours problems $\left(\chi^{2}{ }_{1}=13.29, \mathrm{p}<0.001 ; 25.5 \%\right.$ vs. $\left.16.6 \%\right)$. There was also a sizeable decreases in prevalence for owned housing problems $(7.9 \%$ vs. $5.0 \%)$, though the difference failed to reach statistical significance $\left(\chi^{2}{ }_{1}=3.36, p=0.067\right)$. Evidently, much of the reduction in problem prevalence for 'any problem' associated with legal framing in Table 5 was a consequence of specific reductions for consumer and neighbours problems.

\section{B. $\quad$ Experiment 4 - Lists vs. multiple questions about use of advisers and processes}

As explained above, where respondents had one or more problems, a single problem progressed to questions about advice seeking and use of formal processes. Of 565 problems progressing to these questions, 266 were randomized into a group where use of advice/processes was asked about using a single question (i.e. a list), while 290 were randomized into a group asked multiple questions, with one for each adviser or process.

Where respondents were presented with single questions, 33.5 per cent suggested that they had obtained advice from one or more of the adviser types presented (89 of 266 problems). Where a list was presented, advice seeking increased to 37.9 per cent (110 of 290 problems). A simple chi-squared test indicated that this difference was non-significant $\left(\chi^{2}{ }_{1}=1.21, \mathrm{p}=0.27\right) \cdot{ }^{34}$ However, differences were apparent when conducting analysis at the level of individual advisers. Results from a multivariate binary logistic regression analysis modelling use of each adviser/process on the basis of whether they were presented to respondents in a single list or as multiple questions are shown in Table 8. The covariance matrix associated with the model in Table 8 is shown in Table 9.

The first finding of note in Table 8 is that all 'multiple questions' terms were positive, indicating an increase in reporting of all adviser and process types when compared to those who received a single list. Moreover, there were statistically significant increases in the likelihood of reporting use of a regulator (testing the model term; $\chi^{2}{ }_{1}=$ $4.99, \mathrm{p}=0.025)$, as well as contact with a court or tribunal $\left(\chi^{2} 1=4.23, \mathrm{p}=0.040\right)$ and arranging mediation $\left(\chi^{2} 1_{1}=9.00, \mathrm{p}=0.003\right)$. Increases for 'other' advisers $\left(\chi^{2}{ }_{1}=3.60, \mathrm{p}=\right.$ $0.058)$ and a hearing having taken place $\left(\chi^{2}{ }_{1}=3.17, \mathrm{p}=0.075\right)$ also fell marginally short of significance. In contrast, increases were small and differences non-significant for use of solicitors $\left(\chi^{2}{ }_{1}=0.17, \mathrm{p}=0.68\right)$ and the police $\left(\chi^{2}{ }_{1}=0.03, \mathrm{p}=0.86\right)$, though it is unclear whether this was a function of their prevalence and levels of recognition, or placement in the list. Figure 1 shows the percentage of respondents reporting each adviser and process by whether they were presented in a single list or in multiple questions.

\footnotetext{
${ }^{34}$ Note, that also controlling for problem type in a binary logistic regression model, the increase in advice seeking as sociated with form of question remained non-significant (testing the model term, Wald $1=0.77, \mathrm{p}=$ $0.38)$.
} 
Table 8: Multivariate Binary Logistic Regression of use of Each Adviser or Process Type on the Basis of Whether They Were Presented to Respondents in a Single List or as Multiple Questions (Significant Terms $(\mathrm{p}<0.05)$ in Bold).

\begin{tabular}{|l|c|c|c|c|}
\hline Response variables & \multicolumn{2}{|c|}{ Constant } & \multicolumn{2}{c|}{$\begin{array}{c}\text { Form of question } \\
\text { Multiple questions }\end{array}$} \\
\hline Adviser type & B & SE & B & SE \\
\hline Solicitor & $\mathbf{- 2 . 3 6}$ & $\mathbf{0 . 2 2}$ & 0.12 & 0.30 \\
\hline Advice agency & $\mathbf{- 2 . 0 6}$ & $\mathbf{0 . 1 9}$ & 0.37 & 0.25 \\
\hline Police & $\mathbf{- 2 . 4 6}$ & $\mathbf{0 . 2 3}$ & 0.05 & 0.31 \\
\hline Regulator & $\mathbf{- 2 . 9 7}$ & $\mathbf{0 . 2 8}$ & $\mathbf{0 . 7 7}$ & $\mathbf{0 . 3 5}$ \\
\hline Other & $\mathbf{- 2 . 3 6}$ & $\mathbf{0 . 2 2}$ & 0.53 & 0.28 \\
\hline Process & & & & \\
\hline Court/tribunal contact & $\mathbf{- 3 . 7 7}$ & $\mathbf{0 . 4 1}$ & $\mathbf{0 . 9 9}$ & $\mathbf{0 . 4 8}$ \\
\hline Mediation arranged & $\mathbf{- 3 . 9 6}$ & $\mathbf{0 . 4 5}$ & $\mathbf{1 . 5 0}$ & $\mathbf{0 . 5 0}$ \\
\hline Hearing took place & $\mathbf{- 4 . 1 8}$ & $\mathbf{0 . 5 0}$ & 1.04 & 0.58 \\
\hline Hearing attended & $\mathbf{- 4 . 1 8}$ & $\mathbf{0 . 5 0}$ & 0.95 & 0.59 \\
\hline Court/tribunal decision & $\mathbf{- 3 . 7 7}$ & $\mathbf{0 . 4 1}$ & 0.71 & 0.50 \\
\hline
\end{tabular}

Notes: *compared to the reference category where advisers and processes were presented as a single list.

Table 9: Covariance Matrix Associated With the Model in Table 4

\begin{tabular}{|c|c|c|c|c|c|c|c|c|c|}
\hline & 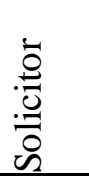 & 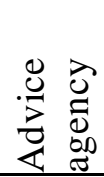 & 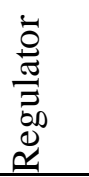 & 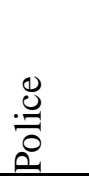 & $\begin{array}{l}\overline{0} \\
\stackrel{ \pm}{0}\end{array}$ & $\begin{array}{l}\stackrel{\bar{\Xi}}{\Xi} \\
\stackrel{\Xi}{\Xi} \\
ن \\
\end{array}$ & . & 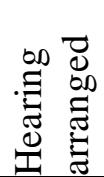 & 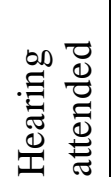 \\
\hline Advice agency & 0.17 & & & & & & & & \\
\hline Regulator & 0.09 & 0.07 & & & & & & & \\
\hline Police & 0.11 & 0.17 & 0.02 & & & & & & \\
\hline Other adviser & 0.10 & 0.13 & 0.07 & 0.10 & & & & & \\
\hline Court/trib. contact & 0.16 & 0.16 & 0.08 & 0.21 & 0.17 & & & & \\
\hline Mediation & 0.20 & 0.17 & 0.03 & 0.04 & 0.22 & 0.15 & & & \\
\hline Hearing arranged & 0.18 & 0.20 & 0.11 & 0.17 & 0.10 & 0.69 & 0.16 & & \\
\hline Hearing attended & 0.11 & 0.16 & 0.09 & 0.05 & 0.02 & 0.62 & 0.14 & 0.64 & \\
\hline Court/tribunal decision & 0.10 & 0.17 & 0.07 & 0.09 & 0.06 & 0.53 & 0.12 & 0.70 & 0.53 \\
\hline
\end{tabular}

Differences between presenting a list compared to multiple questions were also well illustrated by differences in the total number of positive responses to questions/options between conditions. Of those saying 'yes' to at least one of the question or options, where a list was presented 74.2 per cent answered 'yes' to only one, compared to 52.2 per cent for multiple questions. Moreover, only 3.1 per cent of the 'list' group answered 'yes; to four or more options, compared to 15.6 per cent answering 'yes' to four or more individual questions.

Figure 1: Percentage of respondents reporting each adviser and process by whether they were presented in a single list or in multiple questions 


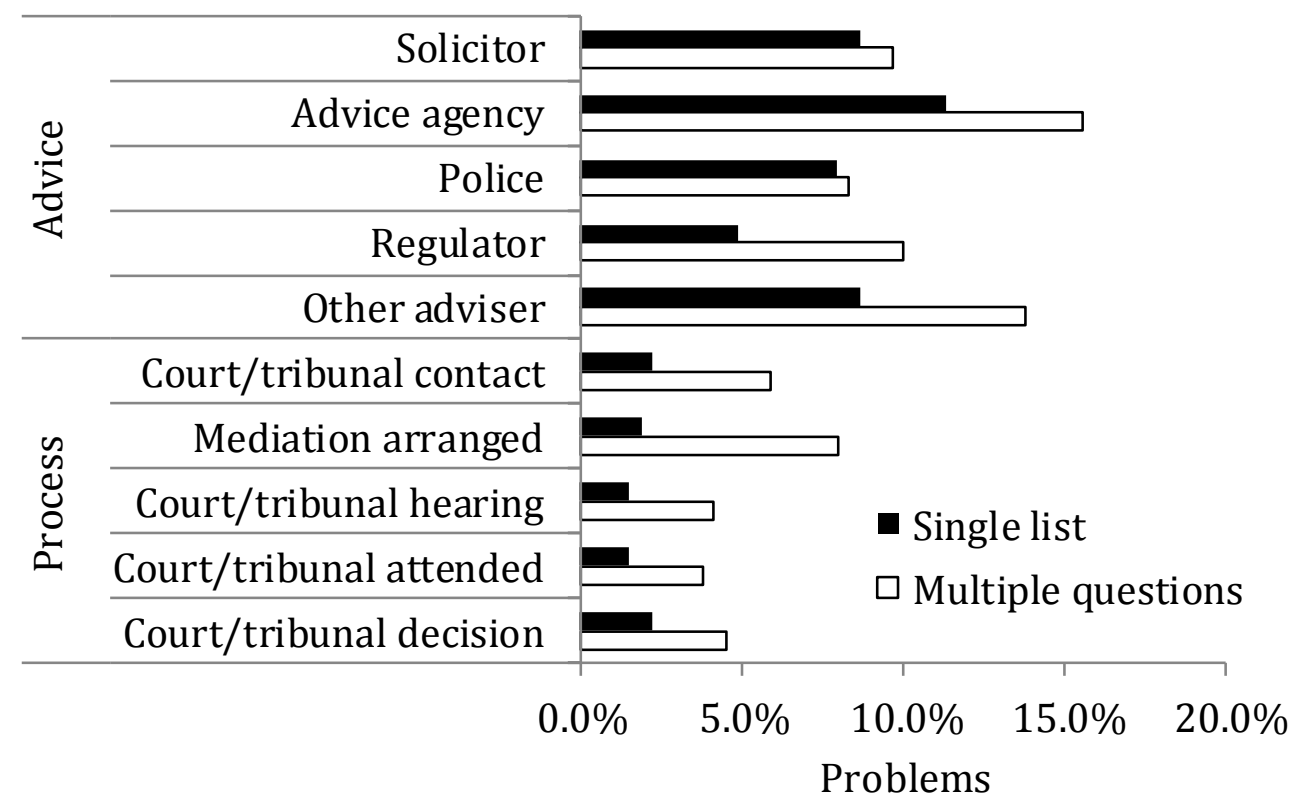

C. Experiment 5 - 'Difficult to solve' phrasing in problem prevalence

Of 625 survey respondents, 15.5 per cent (97 of 625) reported a problem concerning antisocial neighbours, 35.5 per cent (222 of 625) a problem with faulty goods and services, 19.5 per cent (122 of 625) an employment problem and 49.1 per cent (307 of 625) any of the three. However, the inclusion of the words 'difficult to solve' in the problem identification questions had a significant impact on problem prevalence. Examining the three problem types individually, Table 10 shows output from a multivariate binary logistic regression model, with the binary problem identification questions (for neighbours, consumer and employment problems) forming the three response variables and predictor terms included for each for whether 'difficult to solve' was excluded from the phrasing of the problem identification questions. Since a single multivariate model was fitted, the respondent level covariance matrix is shown in Table 11, highlighting the tendency for consumer problems to occur in combination with both neighbours and employment issues.

Table 10: Multivariate Binary Logistic Regression Model of Experience of Three Problem Types on the Basis of Whether or Not 'Difficult to Solve' Was Included in Problem Identification Questions (Significant Terms $(\mathrm{p}<0.05)$ in Bold).

\begin{tabular}{|l|c|c|c|c|}
\hline Response variables & \multicolumn{2}{|c|}{ Constant } & \multicolumn{2}{c|}{ Phrasing } \\
'Difficult to solve' excluded $^{*}$
\end{tabular}

Notes: *Compared to a reference category where problem identification asked for issues that were 'difficult to solve'. 
Table 11: Respondent Level Covariance Matrix Associated With the Model in Table 6

\begin{tabular}{|l|l|c|}
\hline & Neighbours & Good and services \\
\hline Goods and services & $0.19(0.04)$ & - \\
\hline Employment & $0.04(0.04)$ & $0.25(0.04)$ \\
\hline
\end{tabular}

As shown in Table 6, excluding 'difficult to solve' from problem identification questions related to significant increases in the reporting of consumer problems (testing the model term in Table 6; 14.84, $\mathrm{p}<0.001)$ and employment problems $\left(\chi^{2}{ }_{1}=4.97, \mathrm{p}=0.026\right)$, but not neighbours problems $\left(\chi^{2}{ }_{1}=0.324, \mathrm{p}=0.57\right)$. In percentage terms, 42.9 per cent of respondents reported consumer, 23.1 per cent employment and 16.3 per cent neighbours problems where 'difficult to solve' was excluded, compared to 28.1 per cent, 16.0 per cent and 14.7 per cent where it was excluded. More generally, using an 'any problem' category (i.e. whether or not respondents reported any of the three problem types), where 'difficult to solve' was included, 40.6 per cent reported one or more problem (127 of 313) compared to 57.7 per cent where it was excluded (180 of 312 ). This difference was highly significant $\left(\chi^{2} 1=18.32, \mathrm{p}<0.001\right)$.

\section{Discussion}

The evidence from other fields and the findings of our five experiments demonstrate clearly that relatively small changes to survey methods can have a significant impact on findings.

The findings of our first experiment indicate that changes to a legal needs survey's reference period do not lead to a proportional change in the number of justiciable problems reported, but they are likely to impact on the nature of problems reported (Pleasence, Balmer and Tam 2009). Longer reference periods will capture a greater proportion of more serious problems (Sudman and Bradburn 1973, Tourangeau et al 2000), and will, as a consequence, yield different proportions of problems of different categories (Pleasence, Balmer and Tam 2009).

As with Pleasence, Balmer and Tam's analysis of recall over the 2001, 2004 and 2006 English and Welsh surveys' reference periods, problems concerning debt appeared to be quickly forgotten (and so insensitive to reference period duration), while negligent accidents appeared to be only slowly forgotten (and so sensitive to reference period duration). However, not all our findings were consistent with that earlier analysis - perhaps owing in part to the relatively small number of problems available for analysis in some problem categories. Particularly discrepant was our findings that the rate of reporting of divorce did not change with the move from a one to three year reference period! Any change in the nature of problems reported, following on from a change in survey reference period, can also be expected to impact on reported problem resolution behaviour. Problem resolution behaviour has been repeatedly shown to link to both problem seriousness (e.g. Pleasence et al 2004a, Dignan 2006, Kritzer 2008, Pleasence, Balmer and Reimers 2011, Chen et al 2012, Pleasence and Balmer 2012) and problem type (e.g. Reese and Eldred 1994, Genn 1999, Maxwell et al 1999, Genn and Paterson 2001, GfK Slovakia 2004, Van Velthoven and ter Voert 2004, Currie 2006, Dignan 2006, Pleasence 2006, Murayama 2007, Sato et al 2007, Asia Consulting Group Limited and Policy 21 Limited 2008, Kritzer 2008, Pleasence and Balmer 2008, Van Velthoven and Haarhuis 2010, Pleasence et al 2011, Chen et al 2012, Coumeralos et al 2012).

The findings of our second experiment indicate that even a subtle change in survey framing can have a substantial impact on how respondents answer questions. The addition of a single word ('legal') on a single page (the introduction page) of an Internet survey brought about an almost $15 \%$ reduction in the rate at which problems were reported. And 
again, this change was observed to upset the mix of problems reported. So, for example, problems concerning consumer transactions or neighbours appeared not to be regarded as legal, while other problems - such as divorce, negligent accidents and rented housing were. This ties in with Pleasence, Balmer and Reimers (2011) finding that around threequarters of people put a legal label on divorce, negligent accidents and problems concerning rented housing of the type included in our experiment, while only slightly more than one-third put a legal label on problems concerning anti-social neighbours, and just over one-half problems concerning consumer transactions.

Again, an effect of problem mix changing as a result of changes to survey framing is likely to be differences in reported patterns of problem resolution behaviour. In this case, a narrowing of problems to those perceived as having a legal dimension will doubtless yield an increase in reported lawyer use. Pleasence, Balmer and Reimers (2011) found that labelling a problem as legal significantly increased the likelihood that a lawyer would be suggested as an appropriate source of advice about the problem. Corroborating this, respondents to the 2010 English and Welsh Civil and Social Justice Survey who characterized problems as legal reported obtaining help from a lawyer more than twice as often as those who did not characterize them in this way (Pleasence \& Balmer 2014).

The findings of our fourth experiment indicate that very different results can be obtained depending upon whether a single question, with a list of options, or a series of separate questions, one for each option, are used to identify where respondents obtain help and which processes they make use of in resolving their problems. Within the experiment, the reported use of regulators dropped sharply when respondents were presented with a list of sources of help, rather than a series of separate questions about specific sources of help. Also, reports of court process and mediation dropped substantially when included only in a list.

This may lie behind the near significant drop in reports of mediation between the 2006-9 (separate questions) and 2010 (list) English and Welsh surveys, although there was little difference in the rate at which formal court process was mentioned between the two surveys.

The findings of our fifth experiment demonstrate that the inclusion in the problem identification question of the 'difficult to solve' form of triviality filter reduced the rate of problem reporting by $30 \%$. Furthermore, as with changes to the reference period and survey framing, the effect of the 'difficult to solve' triviality filter was not uniform across problem types. Our findings suggest that respondents found problems with anti-social neighbours more difficult to solve than problems concerning consumer transactions or employment.

This is not the only reason that the 'difficult to solve' triviality filter may disrupt findings around problem resolution strategy. More problematic than it reducing the number of less serious problems reported is its conflation of problem incidence and strategy. As Coumeralos et al (2012, p.11) have observed, problems may not be captured simply "because they were easy to handle," which goes straight to capability, which links to problem resolution behaviour (Balmer et al 2010). The removal of the filter should therefore lead to a higher proportion of problems being reported that are handled without recourse to help. Thus, as was noted above, while the rate of inaction remained the same between the 2006-9 and 2010 English and Welsh surveys, the rate of formal advice dropped from $49 \%$ to $29 \%$.

The third experiment was the only one of the five experiments not to demonstrate a significant impact of modification of survey design. The findings suggested that no significant difference in the rate of problem reporting followed a change to the level of detail provided in problem descriptions shown to respondents. Given the findings of earlier 
studies (Groves et. al., 2009; Shaeffer and Presser, 2003), it seems unlikely that substantial changes to the form of questions would have no impact. It is possible that the impact may have varied by problem type and the overall picture become confused. Although no results reached significance, there was some indication that detail differentially affected responses to questions about different problem types. For most problems additional detail was associated with, if anything, an increase in problem reporting. However, in the case of problems ancillary to relationship breakdown the model suggested (albeit just short of the 95\% significance level) that a reduction in incidence accompanied an increase in detail. This is what might be expected of a change from questioning about disputes following relationship breakdown (which could embrace a broad range of arguments) to disputes concerning (the relatively narrow range of) maintenance, child support or residence and contact with children. It is possible, therefore, that had the experiment had larger numbers of participants differences would have become visible at the problem type level.

It is also possible that the effect of providing additional memory cues was offset by the narrowing of the potential range of the problem categories. As Groves et al., (2009) have suggested, detail can increase or decrease prevalence depending on how a question is interpreted.

\section{A. Where Next for Comparative 'Legal Need' Research?}

In light of the above, there is evidently a need for real caution when comparing headline figures (whether they relate to problem incidence, resolution strategy, process or outcome) stemming from different legal need surveys, even where surveys appear to share a commonality of approach. While it is evident that real differences exist between citizens' experiences of and responses to justiciable problems in different jurisdictions (Genn \& Paterson 2001), in most instances we have little basis on which to ascertain the extent to which reported differences reflect underlying reality.

As seen in Table 1, where a series of surveys has been undertaken in a single jurisdiction using substantially the same methods (e.g. the Canadian Survey of Civil Justice Problems, Dutch Paths to Justice Survey and English and Welsh Civil and Social Justice Surveys up to 2009) a good deal of consistency in headline findings has been evident (although even here it is important to be aware of the potential impact of small changes in framing and questionnaire design that might have contributed to observed differences). However, there is generally only superficial consistency of approach and method in respect of recent legal need surveys undertaken in different jurisdictions, despite them almost all forming part of a Paths to Justice tradition of surveys. Consequently, aside from the very real questions that surround the substantially different incidence rates and problem resolution strategies reported by respondents to the near identical English and Scottish Paths to Justice surveys, ${ }^{35}$ it is debatable whether any useful comparison of headline incidence/strategy figures is possible between surveys undertaken in different jurisdictions to date. ${ }^{36} \mathrm{We}$ simply do not know to what extent differences represent methodological artefacts.

As indicated in Table 2 recent legal need surveys have employed different sample structures, modes of administration, framing, reference periods, approaches to excluding trivial problems, and numbers and types of justiciable problem for investigation. Each of

\footnotetext{
35 Other than the subtle differences we have identified in how the surveys were presented to respondents in advance letters, minor changes to a small number of show cards to reflect differences in available services, and different personnel undertaking fieldwork (albeit they were working for the same organisation), the two Paths to Justice Surveys were identical.

36 Once exception to this could be for the Northern Irish survey and English and Welsh Civil and Social Justice Survey, which used the same general methodology and set of core questions.
} 
these can be expected to influence responses. Beyond this, there are also differences in structure, language and terminology that permeate all aspects of the questionnaires used.

\section{B. Patterns of Problems and Patterns of Vulnerability}

However, this does not mean that there is no scope for comparative work. For example, while the absolute rates of problem incidence cannot by compared across jurisdictions, the relative rates of incidence of particular problem categories provide some interest where there are equivalent definitions, particularly when set within a theoretical framework. So for example, Van Velthoven and ter Voert (2005) have argued, referencing participation theory, that problems can be expected to increase along with participation in economic and social life, with problems related to the most frequent forms of activities the most frequent forms of problems. Similarly, Pleasence et al (2004a, p.28) have argued that "the frequency of reporting of different problem types in large part reflects the frequency of experience of the 'defining circumstances' from which they can arise." Thus, 'the most common problems arise from circumstances routinely experienced across the adult population."

So, reflecting the routine nature of consumer transactions, of the 20 recent national legal need surveys for which findings are available, (at least ${ }^{37}$ ) 12 indicated that problems in the consumer category (i.e. problems concerning defective goods and services) were the most frequently reported, and 18 indicated that consumer problems were among the three categories of problems that were most often reported. Similarly, reflecting the frequency of interaction between neighbouring households, problems concerning neighbours were among the three most common problem categories for all 13 surveys that included neighbours problems as a distinct category. And reflecting the centrality of money in life, problems concerning money were found to be among the three most common problem categories in 15 of 18 surveys for which findings are available.

The similarity of patterns of vulnerability to particular types of problems as between recent legal needs surveys also provides some interest.

As problem experience is tied to experience of the defining circumstances of problems, this entails that "experience of them varies between different population groups" (Pleasence et al 2004a, p.29). On top of this, it has been argued that "people's physical make-up, experience, resources and disposition will also affect their vulnerability to experiencing problems" (Pleasence et al 2004a, p.30).

Following on from this, it is to be expected that similar patterns of experience might manifest around the world, and where there are differences these might constitute useful sites for research.

Evidently, differences in the problems included and demographic data collected through surveys, along with the many differences in methods just outlined and explored, militate heavily against even theory driven comparison. Here, though, once a problem is identified as consistent across jurisdictions, and comparable demographic data is available, then each survey provides an opportunity to test relative incidence (within surveys) related hypotheses originating from participation theory, etc..

Unfortunately, a problem for reviewing patterns of findings across jurisdictions is that there has been little consistency in analytical approach and, quite incredibly (given the cost of undertaking national surveys on the scale of those detailed in Table 1), sometimes very little analysis at all (Pleasence, Balmer and Sandefur, 2013). In fact, demographic patterns of experience have only been reported in respect of 14 of the 22 recent national

\footnotetext{
37 The two Paths to Justice surveys did not report findings in a way that allowed different types of family and housing problems to be easily aggregated, meaning that in both instances consumer prob lems could have been in the top three problem categories in terms of incidence.
} 
legal need surveys that have been reported on in English, and one of these was the original Paths to Justice survey, which only collected gender and age data for the full sample. Moreover, multivariate analysis has only been conducted in relation to 6 of these 14 surveys, with 2 being in the same jurisdiction (England and Wales), and one having had findings reported for only one variable (health status) across all problem types (see Pleasence, Balmer and Sandefur, 2013). This is a shame, as only multivariate analysis is able to control for the differences in problem mix that are inevitably thrown up by different survey designs. Nonetheless, exploration of demographic patterns of problem experience, preferably with standardised multivariate analyses, matched problem categories and standard predictors, could be a useful starting point for hypothesis led cross-jurisdictional analysis.

\section{C. $\quad$ Problem Resolution Strategies}

Because many of the design effects detailed above impact on the mix of problems that are reported through legal need surveys, comparative analysis of problem resolution behaviour is even more treacherous than analysis of patterns of problems and patterns of vulnerability. Rates of action, advice, lawyer use and court process are all highly sensitive to the nature and mix of problems reported. Thus, in this area, particular heed needs to be paid to the nature and mix of reported problems, and simple comparison of findings from analyses which do not account for possible differences (i.e. univariate analyses) should always be avoided.

Unfortunately, aside from having to deal with differences in the way that problem resolution behaviour has been captured in different legal need surveys (see Pleasence, Balmer and Sandefur, 2013), ${ }^{38}$ cross-jurisdictional theory driven analysis in this area is (again) limited by the paucity of reported findings from recent surveys. While demographic and problem associations with inaction in the face of problems have been reported for 16 surveys, multivariate analysis has been reported for only 6 .

\section{Conclusion}

It would be a brave person who would be confident in drawing any comparisons between headline problem incidence and strategy rates reported for the great majority of the Paths to Justice tradition legal needs surveys. This is despite their common approach and structure. There are simply too many methodological differences between them to allow for the direct comparison of specific figures. Furthermore, there is no way in which results could be modified to reflect key methodological differences. As we have detailed above, to ascertain the impact of methodological differences as between all the surveys undertaken, would require the conduct of a whole range of probability surveys, in the different jurisdictions and using different modes of delivery!

However, that is not to say that there is no value in comparing the patterns of incidence and behaviour reported from the surveys. Here, precise numbers are of less importance than associations, and provided that analyses are undertaken carefully (so as to ensure likeness of the subjects of study) and employ multivariate techniques (to reduce the influence of any differences in the nature and mix of reported problems) there is the some potential for theory driven cross-jurisdictional analysis, and perhaps even the identification of similarities and differences between broad patterns of experience between jurisdictions.

\footnotetext{
38 This is particularly a problem in relation to inaction, which is generally a residual category into which respondents are placed if they do not report having undertaken any of a (generally diffe rently) defined set of actions.
} 
Unfortunately, the key word in the last sentence was 'potential'. There are surprisingly few detailed analyses of data from the 29 surveys set out in Table 1, and few have been co-ordinated to maximise the possibilities for comparison.

Nevertheless, those analyses of legal needs survey data that have been undertaken to date have revealed a range of seemingly common and contrasting forms of experience and behaviour; some of which - such as patterns of problem clustering (e.g. Pleasence et al. 2004c, Currie 2005, Coumarelos et al. 2012) and the relationship between vulnerability to justiciable problems and physical and psychiatric morbidity (e.g. Pleasence et al. 2004b, Currie 2007b, Balmer et al. 2010, Coumarelos et al. 2014) - have had significant influence on legal service development and delivery in recent years (Pleasence, Balmer and Sandefur, 2013). Important cross-jursdictional insights also continue to emerge; especially from the work being undertaken in the United Kingdom, Australia, Japan, and Taiwan, where there is currently the most in-depth research activity in this area. For example, studies in the United Kingdom, Australia and Taiwan have started to expose common relationships between the use of lawyers, income and fee mechanisms/public subsidies for legal services (Pleasence \& Balmer 2012, Pleasence \& Macourt 2013, Huang et al. 2014). There is also clear indication that, as well as the much smaller proportion of lawyers in Japan, there are also important social differences between Japan and the West that inhibit wider lawyer use. Crucially, access to lawyers in Japan appears to be significantly dependant on introductions (Murayama 2009). This makes apparent the importance of less traditional legal advice centres in achieving access to justice.

Moreover, while there is limited scope for direct comparison of findings between legal needs surveys conducted in different jurisdictions, this does not diminish the richness and utility of findings that have been reported from some individual surveys to date; a richness and utility that extends well beyond the common and contrasting patterns alluded to in the previous paragraph. And, of course, findings in one jurisdiction can inspire research in another, meaning that surveys can provide more than the sum of their parts through means other than comparative analysis.

However, there is still some way to go to achieve a rich body of comparative literature drawing on legal need surveys. But, perhaps, if the methodological insights that have arisen through the undertaking of past surveys, along with interest in promoting greater potential for comparative analysis, can lead to future surveys learning, building upon and standardising best practice, then who knows.

We therefore end by echoing the words of Cantril (1996, p.7), who said after the completion of the Comprehensive Legal Needs Study that people should "draw on the experience with the Comprehensive Legal Needs Study to improve the methodology of legal needs surveys and identify important topics for further study." We now have 28 recent surveys to learn and draw from. 
References

Access to Justice Study Committee (2007) Bridging the Justice Gap: Wisconsin's Unmet Legal Needs. Madison, WI: State Bar of Wisconsin.

Asia Consulting Group and Policy 21 (2008) Consultancy Study on the Demand for and Supply of Legal and Related Services, Hong Kong: Department of Justice.

Baker, R., S.J. Blumberg, J.M. Brick, M.P. Couper, M. Courtright, J.M. Dennis, D. Dillman, M.R. Frankel, P. Garland, R.M. Grovers, C. Kennedy, J. Krosnick, and P.J. Lavrakas (2010) "Research Synthesis: AAPOR Report on Online Panel," in Public Opinion Quarterly DOI: 10.1093/poq/nfq048

Baxter, J., Trebilcock, M. and Yoon, A. (2012) "The Ontario Civil Legal Needs Project: A Comparative Analysis of the 2009 Survey Data," in Trebilcock, M., Duggan, A. and Sossin, L. (eds.) Middle Income Access to Justice. Toronto: University of Toronto Press.

Balmer, N.J., Pleasence, P. and Buck A. (2010) "Psychiatric Morbidity and the Experience of Problems Involving Rights," in 18(6) Health and Social Care in the Community, pp.588-597.

Bishop, G., Hippler, H., Schwarz, N., and Strack, F. (1988) "A Comparison of the Response Effects in Self-Administered and Telephone Surveys," in Groves, R., Biemer, P., Lyberg, L., Massey, J., Nicholls II, W., and Waksberg, J. (eds.), Telephone Survey Methodology, pp. 321-340, New York: Wiley.

Blacksell, M., Economides, K. and Watkins, C. (1991) Justice Outside the City: Access to Legal Services in Rural Britain. Essex: Longmans.

Blumberg, S.J. and Luke, J.V. (2007) "Coverage Bias in Traditional Telephone Surveys of Low-Income and Young Adults," in 71(5) Public Opinion Quarterly, pp.734-749.

Bogart, W. A. and Vidmar, N. (1990) "Problems and Experience with the Ontario Civil Justice System," in Hutchinson, A. (ed.) Access to Civil Justice, Toronto: Carswell.

Bowling, A. (2005) "Mode of questionnaire administration can haveserious effects on data quality," in 27 Journal of Public Health, pp. 281-291.

Bradburn, N.N. (1992) "A Response to the Non-Response Problem," in 56 Public Opinion Quarterly, pp.391-397.

Callegaro, M., and DiSogra, C. (2008) "Computing Response Metrics for Online Panels," in 72(5) Public Opinion Quarterly, pp.1008-1032.

Callegaro, M., Baker, R., Bethlehem, J., Goritz, A.S., Krosnick, J.A. and Lavrakas, P.J.

(2014) Online Panel Research: A Data Quality Perspective, Chichester: Wiley.

Cantril, A.H. (1996) Final Report on the Implications of the Comprehensive Legal Needs Survey, Chicago: American Bar Association.

Chen, K.-P., Huang, K.C. and Lin, C.C. (2012) The Research Design and Methodology of the 2011 Civil Justice Survey in Taiwan. Paper presented at the Law and Society Association Conference, Honolulu, 7 June 2012.

Chen, K.-P., Huang, K.-C., Huang, Y.-L., Lai, H.-P. and Lin, C.-C. (2012) Exploring Advice Seeking Behaviour: Findings from the 2011 Taiwan Survey of Justiciable Problems. Paper presented at the Law and Society Association Conference, Honolulu, 7 June 2012.

Clark, C. and Corstvet, E. (1938), "The lawyer and the public: an A.A.L.S. survey," in 47 Yale Law Journal, pp.1272-93.

Coumarelos, C., Wei, Z and Zhou, A.Z. (2006) Justice Made to Measure: New South Wales Legal Needs Survey in Disadvantaged Areas. Sydney: Law and Justice Foundation of New South Wales.

Coumarelos, C., Macourt, D., People, J., McDonald, H., Wei, Z., Iriana, R. and Ramsey, S. (2012) Legal Australia-Wide Survey: Legal Need in Australia, Sydney: Law and 
Justice Foundation of New South Wales.

Coumarelos, C., Pleasence, P. and Wei, Z. (2013) Law and Disorders, Sydney: Law and Justice Foundation of New South Wales.

Curran, J. and Blackburn, R.A. (2001) Researching the Small Enterprise, London: Sage.

Curran, B.A. and Spalding, F. (1974) The Legal Needs of the Public, Chicago: American Bar Association and American Bar Foundation.

Currie, A. (2005) A National Survey of the Civil Justice Problems of Low and Moderate Income Canadians: Incidence and Patterns. Ottawa: Department of Justice.

Currie, A. (2007) The legal Problems of Everyday Life: The Nature, Extent and Consequences of Justiciable Problems Experienced by Canadians. Ottawa: Department of Justice.

Currie, A. (2007b) "Civil Justice Problems and the Disability and Health Status of Canadians," in Pleasence, P., Buck, A. and Balmer, N.J. (eds.) Transforming Lives: Law and Social process. Norwich: TSO.

Currie, A. (2009) "The Legal Problems of Everyday Life," in Sandefur, R.L. (ed.) Access to Justice, Bingley: Emerald.

Czaja, R., and Blair, J. (2005). Designing Surveys: A Guide to Decisions and Procedures ( $2^{\text {nd }}$ edition). Tousand Oaks, California: Sage.

de Leeuw, E.D., Hox, J.J., and Dillman, D.A. (2008). International Handbook of Survey Methodology. New York: Taylor \& Francis.

Dignan, T. (2006) Northern Ireland Legal Needs Survey. Belfast: Northern Ireland Legal Services Commission.

Dillman, D.A. (2008) "The Logic and psychology of constructing questionnaires," in de Leeuw, E.D., Hox, J.J. and Dillman, D.A (eds.) International Handbook of Survey Methodology. Hove: Taylor and Francis.

Galesic, M. and Tourangeau, R. (2007) "What is Sexual Harassment? It Depends on Who Asks! Framing Effects on Survey Responses," in 21 Applied Cognitive Psychology, pp.189-202.

Genn, H. (1999) Paths to Justice: What People Do and Think About Going to Law. Oxford: Hart.

Genn, H. and Paterson, A. (2001) Paths to Justice Scotland: What People in Scotland Think and Do About Going to Law. Oxford: Hart.

GfK Slovakia (2004) Legal Needs in Slovakia II. Bratislava: GfK Slovakia.

Goldstein, H. (2011) Multilevel Statistical Models (4 ${ }^{\text {th }}$ edition). Chichester: Wiley.

Groves, R.M., Fowler, F.J., Couper, M.P., Leprowski, J.M., Singer, E. and Tourangeau, R. (2009) Survey Methodology (2 $2^{\text {nd }}$ edition). Hoboken, New Jersey: John Wiley and Sons.

Groves, R.M. and Lyberg, L. (2010) "Total Survey Error. Past, Present and Future," in 74(5) Public Opinion Quarterly, pp.849-879.

Heeringa, S.G., West, B.T. and Nerglund, P.A. (2010) Applied Survey Data Analysis. Boca Raton: Chapman and Hall.

Heerwegh, D., \& Loosveldt, G. (2008). Face-to-Face versus Web Surveying in a HighInternet-Coverage Population: Differences in Response Quality. Public Opinion Quarterly, 72(5), 836-846.

Hofstede, G. (2001) Culture's Consequences. Thousand Oaks: Sage.

Huang, K-C, Lin, C-C and Chen, K-P (2014) "Do Rich and Poor Behave Similarly in Seeking Legal Advice? Lessons from Taiwan in Comparative Perspective," in 48(1) Law and Society Review, pp.193-223.

Ignite Research (2006) Report on the 2006 National Survey of Unmet Legal Needs and Access to Services, Wellington: Legal Services Agency. 
Kish, L. (1987) Statistical Design for Research, New York: Wiley.

Kritzer, H.M. (2008) "To Lawyer or Not to Lawyer: Is That the Question?" in 5(4) Journal of Empirical Legal Studies, pp.875-906.

Krosnick, Jon A. 1991. "Response Strategies for Coping with the Cognitive Demands of Attitude Measures in Surveys." In 5 Applied Cognitive Psychology, pp.213-36.

Legal Services Commission (2006) Making Legal Rights a Reality: The Legal Services Commission's Strategy for the Community Legal Service. London: Legal Services Commission.

Lensvelt-Mulders, G.J.L.M., Lugtig, P.J. and Hubregtse, M. (2009) "Separating Selection Bias and Non-Coverage in Internet Panels Using Propensity Matching," in Survey Practice, September 2009.

Lewis, P. (1973) "Unmet Legal Needs," in Morris, P., White, R. and Lewis, P. (eds.) Social Needs and Legal Action. Oxford: Martin Robertson.

Lord Chancellor's Department (1998) Modernising Justice: The Government's Plans for Reforming Legal Services and the Courts. London: HMSO (Cmd. 4155).

Maxwell, G., Smith, C., Shepherd, P. \& Morris, A. (1999) Meeting Legal Service Needs: Research Report Prepared for the Legal Services Board. Wellington: Legal Services Board.

Michelson, E. (2008) Popular Attitudes towards Dispute Processing in Urban and Rural China. Oxford: The Foundation for Law, Justice, and Society.

Ministry of Justice (2010) Proposals for the reform of Legal Aid in England and Wales. London: HMSO (Cmd. 7976).

Mirlees-Black, C. and Byron, C. (1999) Domestic Violence: Findings From the BCS SelfCompletion Questionnaire, London: Home Office.

Murayama, M. (2007) "Experiences of Problems and Disputing Behaviour in Japan," in 14 Meiji Law Journal, pp.1-59.

Murayama, M. and Cominelli, L. (2011) "Current Socio-Legal Perspectives on Dispute Resolution," in 1(6) Oñati Socio-Legal Series.

Pleasence, P. (2006) Causes of Action: Civil Law and Social Justice, $2^{\text {nd }}$ edition. Norwich: TSO.

Pleasence, P. and Balmer, N.J. (2008) "Understanding Advice Seeking Behaviour: Findings from New Zealand and England and Wales," in Huang, K.C. (ed.) Empirical Studies of Judicial Systems, Taipei: Academia Sinica.

Pleasence, P. and Balmer, N.J. (2012) "Caught in the Middle: Justiciable Problems and the Use of Lawyers," in Trebilcock, M., Duggan, A. and Sossin, L. (eds.) Middle Income Access to Justice. Toronto: University of Toronto Press.

Pleasence, P. Buck, A., Balmer, N.J., O'Grady, A., Genn, H. and Smith, M. (2004a) Causes of Action: Civil Law and Social Justice, $1^{\text {st }}$ edition. Norwich: TSO.

Pleasence, P., Balmer, N.J., Buck, A., O'Grady, A. and Genn, H. (2004b) "Civil Law Problems and Morbidity," in 58(7) Journal of Epidemiology and Community Health, pp.552-557.

Pleasence, P., Balmer, N.J., Buck, A., O'Grady, A. and Genn, H. (2004c) 'Multiple Justiciable Problems: Problem Clusters, Problem Order and Social and Demographic Indicators," 1(2) Journal of Empirical Legal Studies, pp.301-330.

Pleasence, P., Balmer, N.J. and Reimers, S. (2011) "What Really Drives Advice Seeking Behaviour? Looking beyond the Subject of Legal Disputes," in 1(6) Onati SocioLegal Series.

Pleasence, P., Balmer, N.J., Patel, A., Denvir, C. (2010) Civil Justice in England and Wales. London: Legal Services Commission.

Pleasence, P., Balmer, N.J. and Sandefur, R.L. (2013) Paths to Justice: A Past, Present 
and Future Roadmap, London: Centre for Empirical Legal Studies

Pleasence, P., Balmer, N.J. and Tam, T. (2009) 'Failure to Recall: Indications from the English and Welsh Civil and Social Justice Survey of the Relative Severity and Incidence of Civil Justice Problems," in Sandefur, R.L. (ed.) Access to Justice, Bingley: Emerald.

Pleasence, P. Buck, A., Goriely, T., Taylor, J. Perkins, H. and Quirk, H. (2001) Local Legal Need. London: Legal Services Commission.

Pleasence, P., Genn, H., Balmer, N.J., Buck, A., and O'Grady, A. (2003) "Causes of Action: First Findings of the LSRC Periodic Survey," in 30(1) Journal of Law and Society, pp.11-30.

Pleasence, P. and Macourt, D. (2013) What Price Justice? Income and the Use of Lawyers, Sydney: Law and Justice Foundation of New South Wales.

Presser, S., Blair, J. and Triplett, T. (1992) "Survey Sponsorship, Response Rates and Response Effects," in 73 Social Science Quarterly, pp.699-702.

Rasbash, J., Charlton, C., Browne, W.J., Healy, M. and Cameron, B. (2009a) MLwiN Version 2.1. Centre for Multilevel Modelling, University of Bristol.

Rasbash, J., Steele, F., Browne, W.J. and Goldstein, H. (2009b) A User's Guide to MLwiN, v2.10. Centre for Multilevel Modelling, University of Bristol.

Reese, R.W. and Eldred, C.A. (1994) Findings of the Comprehensive Legal Needs Study. Chicago: American Bar Association.

Sato, I., Takahashi, H., Kanomata, N. and Kashimura, S. (2007) Citizens' Access to Legal Advice in Contemporary Japan: Lumpers, Self-Helpers and Third-Party Advice Seekers. Paper presented at the Joint Annual Meeting of the Law and Society Assocation and the Research Committee on Sociology of Law, Humboldt University, Berlin, 26 July 2007.

Schaeffer, N.C. and Presser, S. (2003) "The Science of Asking Questions," in 29 Annual Review of Sociology, pp.65-88.

Schwartz, N., Strack, F., Hippler, H., and Bishop, G. (1991), "The Impact of Administration Mode on Response Effects in Survey Measurement," Applied Cognitive Psychology, 5, pp.3-23.

Stoop, I.A.L. (2005) The Hunt for the Last Respondent: Nonresponse in Sample Surveys. The Hague: Social and Cultural Planning Office of the Netherlands.

Sudburn, S. and Bradburn, N.M. (1973), "Effects of Time and Memory Factors on Response in Surveys", in 68 Journal of the American Statistical Society, pp.805-815.

Sykes, W. and Collins, M. (1988). Effect of Mode of Interview: Experiments in the UK. In: Groves RM, Biemer PP, Lyberg LE, Massey JT, Nichols WL, Waksberg J. Telephone Survey Methodology. New York: Wiley.

Tamaki, T. (2009) "Summary Tables of the Results of an Internet Survey on Dispute Resolution," Part 1 and Part 2, in Niigata University Journal of Law and Politics, Vol 41, No. 3/4, pp.205-240; Vol 42, No. 1, pp.157-180.

Taylor, A.W., Martin, G., Dal Grande, E., Swannell, S., Fullerton, S., Hazell, P. and Harrison, J.E. (2011) "Methodological Issues Associated with Collecting Sensitive Information Over the Telephone: Experience fom an Australian Non-Suicidal SelfInjury (NSSI) Prevalence Study." BMC Medical Research Methodology 11:20.

Tourangeau, R., Rips, L., and Rasinski, K. (2000), The Psychology of Survey Response, Cambridge: Cambridge University Press.

ter Voert, M. and Niemeijer, B. (2007) Varieties in Disputing Behaviour in Different Countries: Explanatory Strategies and Methodological Pitfalls. Paper presented at the Joint Annual Meeting of the Law and Society Assocation and the Research Committee on Sociology of Law, Humboldt University, Berlin, 26 July 2007. 
Trubek, D.M. Grossman, J.B., Felstiner, W.L.F., Kritzer, H.M. and Sarat, A. (1983) Civil Litigation Research Project Final Report. Madison, Wisconsin: University of Wisconsin Law School.

van Velthoven, B.C.J. and ter Voert (2004) Paths to Justice in the Netherlands: Looking for Signs of Social Exclusion. Den Haag, the Netherlands: Ministry of Justice.

van Velthoven, B.C.J. and ter Voert (2005) Paths to Justice in the Netherlands. Paper presented at the International Legal Aid Group Conference, Killarney, June 2005.

Van Velthoven, B.C.J. and Haarhuis (2010) Geschilbeslechtingsdelta 2009: Over Verloop en Afloop van (Potentieel) Juridische Problemen van Burgers. Den Haag, the Netherlands: Ministry of Justice.

Woodhouse, G. and Goldstein, H. (1989). "Educational performance indicators and LEA league tables." In 14 Oxford Review of Education, pp. 301-319 